Marquette University

e-Publications@Marquette

4-1-2005

Synthesis of Cyclopropanes via Organoiron Methodology: Preparation and Rearrangement of Divinylcyclopropanes

Nathaniel J. Wallock

Marquette University

William A. Donaldson

Marquette University, william.donaldson@marquette.edu

Accepted version. Organic Letters, Volume 7, No. 10 (2005): 2047-2049. DOI. (C) 2005 American Chemical Society. Used with permission. 


\title{
Synthesis of Cyclopropanes via Organoiron Methodology: Preparation and Rearrangement of Divinylcyclopropanes
}

\author{
Nathaniel J. Wallock \\ Department of Chemistry, Marquette University, \\ Milwaukee, WI \\ William A. Donaldson \\ Department of Chemistry, Marquette University, \\ Milwaukee, WI
}

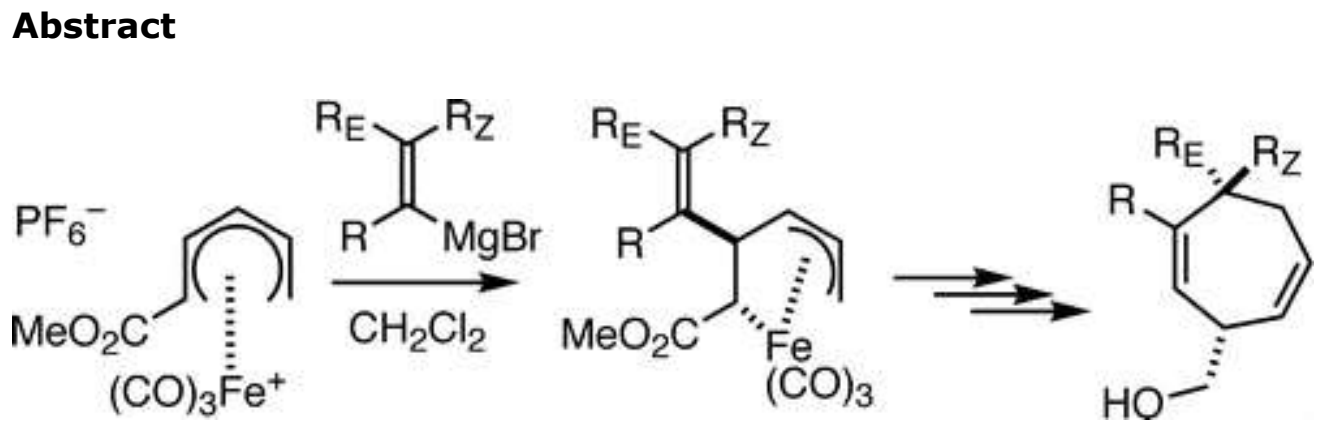

Organic Letters, Vol 7, No. 10 (May 12, 2005): pg. 2047-2049. DOI. This article is @ American Chemical Society and permission has been granted for this version to appear in e-Publications@Marquette. American Chemical Society does not grant permission for this article to be further copied/distributed or hosted elsewhere without the express permission from American Chemical Society. 
NOT THE PUBLISHED VERSION; this is the author's final, peer-reviewed manuscript. The published version may be accessed by following the link in the citation at the bottom of the page.

Addition of alkenyl Grignard reagents to (1-

methoxycarbonylpentadienyl)iron $(1+)$ cation generates the corresponding (2alkenylpent-3-en-1,5-diyl)iron complexes. Oxidatively induced-reductive elimination of these complexes gives divinylcyclopropanes which can undergo subsequent Cope rearrangement to give 1,4-cycloheptadienes.

The Cope rearrangement of cis-divinylcyclopropane (cis-1), which occurs at $<35^{\circ} \mathrm{C}$, is known to afford 1,4-cycloheptadiene ( 2 , Scheme 1$).{ }^{1}$ A variety of methods exist for the preparation of divinylcyclopropanes. Among these are oxo-sulfonium ylide cyclopropanation of enals followed by Wittig olefination of the resultant cyclopropanecarboxaldehyde, ${ }^{2}$ reaction of 2 -metalated vinylcyclopropanes with 3-alkoxy-2-cycloalken-1-ones followed by hydrolysis/dehydration, ${ }^{3}$ and rhodium-catalyzed cyclopropanation of vinyldiazomethanes. ${ }^{4}$

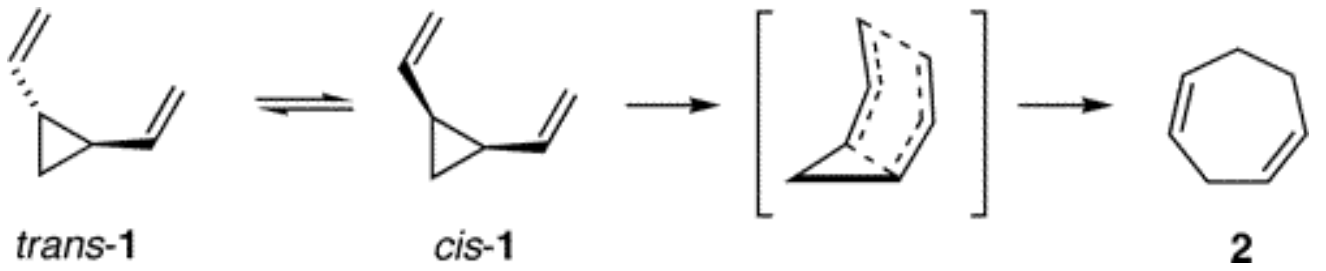

Scheme 1

The addition of stabilized carbon nucleophiles to (1methoxycarbonylpentadienyl)iron( $1+$ ) cation (3) is known to afford stable (pentenediyl)iron complexes (4), which undergo oxidatively induced-reductive elimination to give vinylcyclopropanecarboxylates (5, Scheme 2). ${ }^{5}$ We have utilized this methodology to prepare 2-(2'carboxycyclo-propyl)glycines (6) ${ }^{5 a}$ and the C9-C16 alkenyl cyclopropane segment (7) of ambruticin. ${ }^{5 b}$ We herein report on the preparation and rearrangement of divinylcyclopropanes via this methodology. 


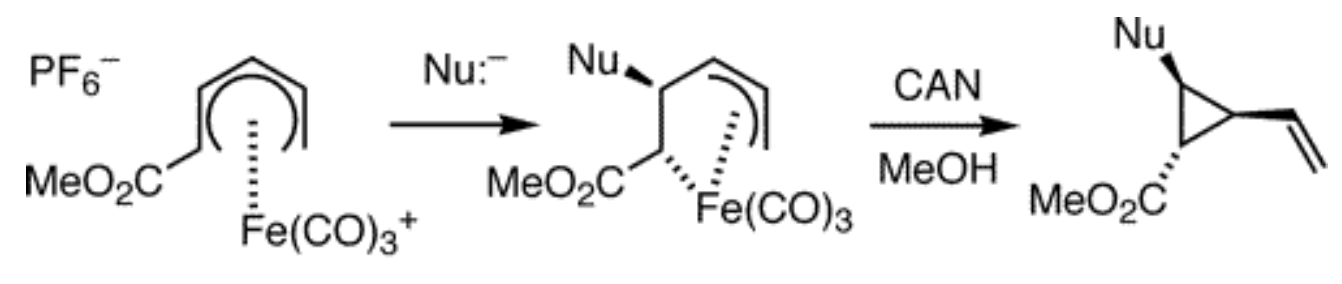

3<smiles>CCC1[C@H](C(N)C(=O)O)[C@@H]1C(=O)O</smiles>

4
5

\section{Scheme 2}

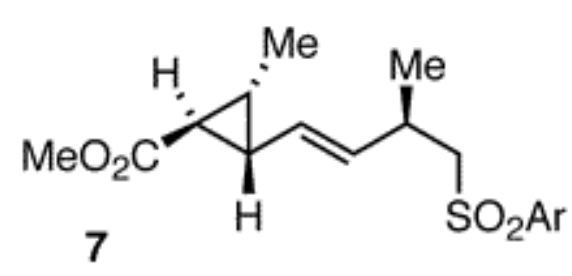

Reaction of cation 3 with vinylmagnesium chloride, in $\mathrm{CH}_{2} \mathrm{Cl}_{2}$, gave the corresponding (2-alkenyl-3-pentene-1,5-diyl)iron complexes $4 a$ (Scheme 3). Use of $\mathrm{CH}_{2} \mathrm{Cl}_{2}$ as solvent is crucial for addition of Grignard reagents at $\mathrm{C} 2$; use of 1,2-dichloroethane, toluene, THF, dioxane, or mixtures led to diminished yields of $\mathbf{4 a}$. The structure of pentenediyl complex 4a was assigned on the basis of its NMR spectral data. In particular, a ${ }^{13} \mathrm{C}$ NMR signal at $\delta 11.4 \mathrm{ppm}$ and a ${ }^{1} \mathrm{H}$ NMR signal at $\delta 0.24$ (d) ppm are characteristic of a carbon $\sigma$-bonded to iron and its attached proton. ${ }^{5}$ 

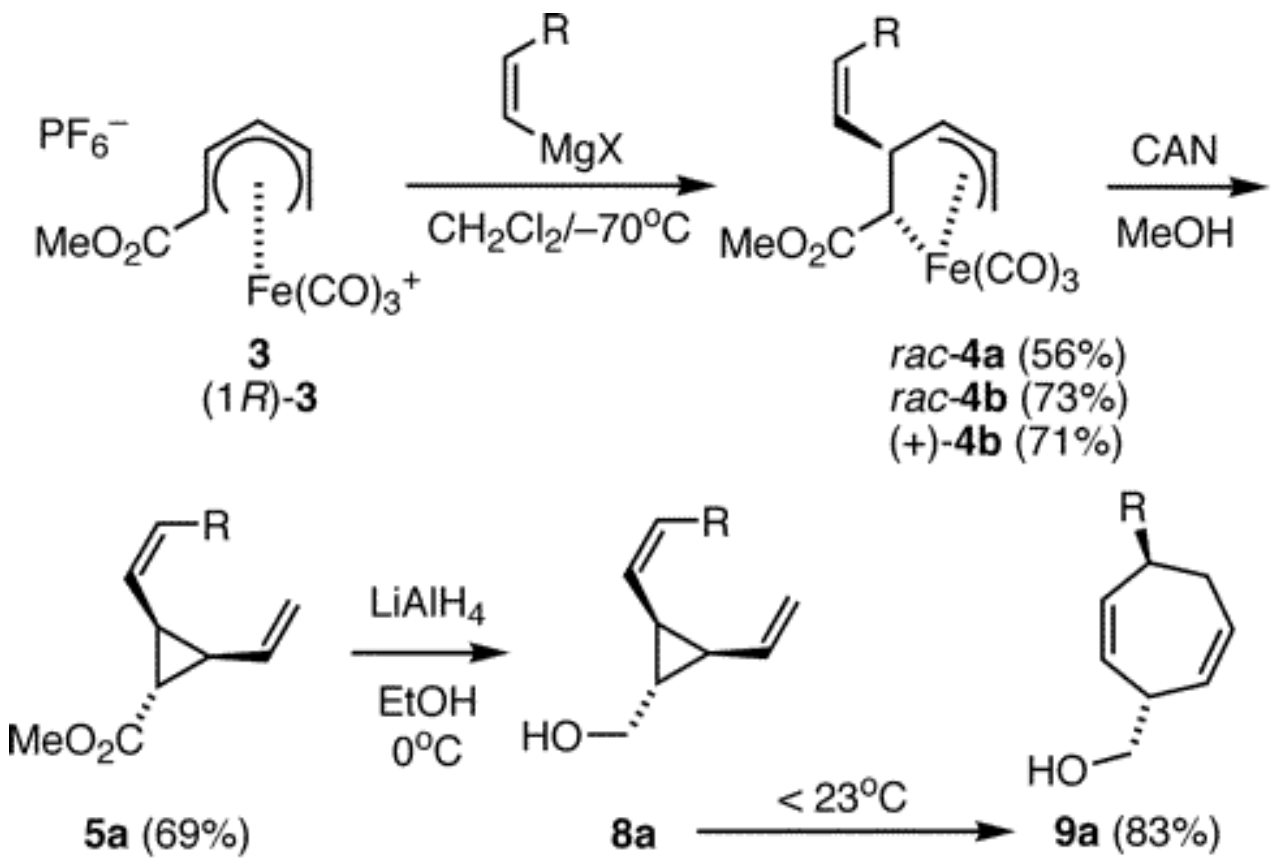

5a $(69 \%)$

rac-5b $(75 \%)$

$(+)-5 b(83 \%)$

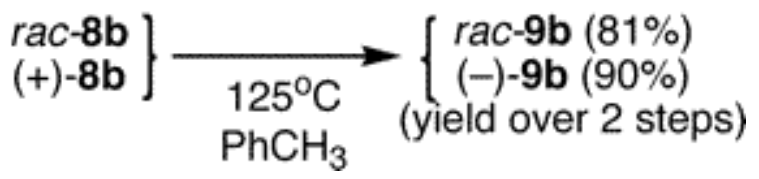

\section{Scheme 3 a}

${ }^{a} \mathbf{a}, \mathrm{R}=\mathrm{H} ; \mathbf{b}, \mathrm{R}=\mathrm{Me}$.

Oxidative decomplexation of $\mathbf{4 a}$ with excess CAN/methanol gave cis-divinylcyclopropane 5a. This compound rearranges at $40-60{ }^{\circ} \mathrm{C}$ to give the known (3-methoxycarbonyl)-1,4-cycloheptadiene. ${ }^{6}$

Alternatively, reduction of the cyclopropanecarboxylate (LAH/ether) gave the rearranged (2,6-cycloheptadien-1-yl)methanol $\mathbf{9 a}$.

Presumably, the intermediate divinylcyclopropane 8a rapidly rearranges at $<23^{\circ} \mathrm{C}$. It is known that the presence of an electronwithdrawing group strengthens the distal cyclopropane ring bond, and this should have an effect on the rate of the Cope rearrangement.

In a similar fashion, reaction of rac-3 with the Grignard reagent prepared from cis-1-propenyl bromide gave rac-4b. Oxidative decomplexation of $\mathbf{4 b}$ gave rac-5b, which upon reduction gave the cyclopropylcarbinol rac-8b. In comparison to the parent divinylcyclopropane $\mathbf{8} \mathbf{a}$, the cis-alkenyl cyclopropane $\mathbf{8 b}$ is stable at ambient temperatures and only rearranges at elevated temperature $\left(125^{\circ} \mathrm{C}\right)$ to give a single cycloheptadiene rac-9b. ${ }^{7}$ This methodology 
can be extended to the enantioselective preparation of cycloheptadienes. Thus reaction of $(1 R)-3^{8}$ with cis-1-propenyl Grignard reagent gave $(+)-\mathbf{4 b}$, which upon oxidative decomplexation gave the optically active divinylcyclopropane $(+)$-5b. Reduction of $(+)$ 5b gave $(+)-\mathbf{8 b}$ which, upon rearrangement at elevated temperature, gave $(-)$-9b. Both $(+)-\mathbf{4 b}$ and $(+)-\mathbf{5 b}$ were determined to be $>95 \%$ ee on the basis of ${ }^{1} \mathrm{H}$ NMR spectroscopy in the presence of a chiral lanthanide shift reagent, while the $(S)$-Mosher's ester of $(-)$-9b was determined to be $>95 \%$ de.

In a similar fashion, reaction of $\mathbf{3}$ with the Grignard reagents derived from 2-bromo-1-propene, a-bromostyrene, 1-bromo-2methylpropene, and 1-bromocyclopentene gave the corresponding (pentenediyl)iron complexes 4c-f (Table 1). Oxidative decomplexation of $\mathbf{4 c}$ gave the divinylcyclopropane $\mathbf{5 c}$ along with the rearranged cycloheptadiene product (ca. 2.5:1, 88\% yield). Reduction of this mixture gave the (2,6-cycloheptadien-1-yl)methanol 9c (Cope rearrangement occurs at $<23^{\circ} \mathrm{C}$ ). In comparison, oxidative decomplexation of (pentenediyl)iron complexes $\mathbf{4 d}$ or $\mathbf{4 e}$, which contain an electron-rich alkenyl group, gave diminished yield of divinylcyclopropane. Further experimentation indicated that this diminished yield was due to secondary oxidation of the divinylcyclopropane product by CAN. For this reason, we explored alternative oxidation conditions, the most successful of which was the use of alkaline hydrogen peroxide at low temperature (conditions B). While the chemical yields under conditions B were good, the products consisted of a mixture of cis- and trans-divinylcyclopropanes, as evidenced by NMR spectroscopy. These mixtures could be converted into a single cycloheptadiene product by the standard reduction/Cope rearrangement conditions. Monitoring of this reaction by VT NMR spectroscopy indicated that the cis-divinylcyclopropane rearranges at temperatures lower than those of the trans isomer; rearrangement of the trans isomer presumably occurs via isomerization to the cis isomer via a diradical opening of the cyclopropane ring. ${ }^{1}$ 
NOT THE PUBLISHED VERSION; this is the author's final, peer-reviewed manuscript. The published version may be accessed by following the link in the citation at the bottom of the page.

Table 1. Preparation of (Pentendiyl)iron Complexes, Divvinylcyclopropanes, and Cycloheptadienes

\begin{tabular}{ccccc}
\hline $\begin{array}{c}\text { pentenediyl } \\
\text { complex }\end{array}$ & $\begin{array}{c}\text { oxidation } \\
\text { conditions }^{\mathrm{a}}\end{array}$ & $\begin{array}{c}\text { divinyl- } \\
\text { cyclopropane }\end{array}$ & $\begin{array}{c}\text { Cope } \\
\text { conditions }^{\mathrm{a}}\end{array}$ & $\begin{array}{c}1,4-\text {-cyclo- } \\
\text { heptadiene }\end{array}$ \\
\hline
\end{tabular}<smiles>C=C(C)[C@H](/C=C\C(=O)OC)[C@@H](C(=O)OC)C(C)(C)C</smiles>

4c $(42-52 \%)$<smiles>C=C(c1ccccc1)C(/C=C\C)C(=O)OC</smiles>

A<smiles>C=C[C@H](C=C(C)C(C)(C)C)[C@@H](C=C(C)C)C(=O)OC</smiles>

A<smiles>C=CC1C(C(=C)C)[C@H]1C(C)C</smiles>

not observed

$$
5 c^{c}
$$

C<smiles>CC1=C[C@H](CO)C=CCC1</smiles>

$6 \mathrm{c}(82 \%)^{b}$<smiles>O=[SbH2]O[Na]</smiles><smiles>C=C[C@H]1[C@@H](C=C(C)C)[C@H]1C(C)=O</smiles>

D<smiles>OC[C@H]1C=CCCC(c2ccccc2)=C1</smiles><smiles>CC(C)(C)[Mg][Mg]</smiles>

$6 \mathrm{e}(80 \%)^{\mathrm{b}}$

$\begin{array}{ll}\text { A } & 5 \mathrm{e}(11 \%, \text { cis only) } \\ \text { B } & 5 \mathrm{e} / \mathrm{e}^{\prime}(63-84 \%)^{\mathrm{d}}\end{array}$

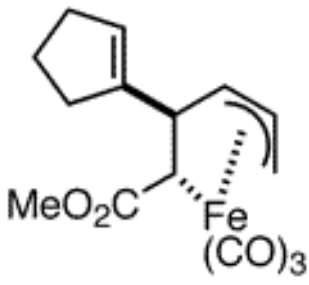

B<smiles>C=C[C@H]1C(C2=CCCC2)[C@H]1C(C)OC</smiles>

E

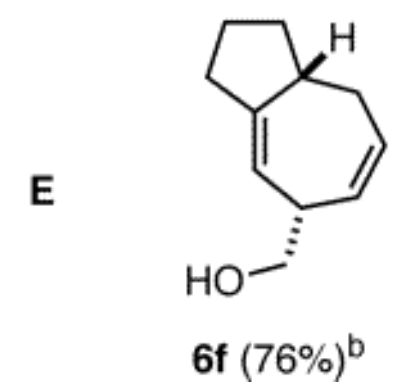

\section{$4 f(50 \%)$}

$$
5 f(85 \%)^{e}
$$

a Decomplexation conditions: $A=$ excess $\mathrm{CAN} / \mathrm{MeOH} / 23^{\circ} \mathrm{C} ; \mathrm{B}=\mathrm{H}_{2} \mathrm{O}_{2} / \mathrm{MeOH} /-45^{\circ} \mathrm{C}$; $\mathrm{C}=\mathrm{LAH}$, then rearrangement at or below $23^{\circ} \mathrm{C} ; \mathrm{D}=\mathrm{LAH}$, then rearrangement at $195^{\circ} \mathrm{C} ; \mathrm{E}=\mathrm{LAH}$, then rearrangement at $210^{\circ} \mathrm{C} .{ }^{b}$ Yield over three steps (decomplexation, LAH reduction, and Cope rearrangement). ${ }^{c}$ Obtained as a mixture with the cycloheptadiene $2.5: 1){ }^{d}$ Divinylcyclopropane obtained as a mixture of cis and trans isomers $(1: 1) .{ }^{e}$ Divinylcyclopropane obtained as a mixture of cis and trans isomers (ca. $1: 2.5$ ).

Organic Letters, Vol 7, No. 10 (May 12, 2005): pg. 2047-2049. DOI. This article is @ American Chemical Society and permission has been granted for this version to appear in e-Publications@Marquette. American Chemical Society does not grant permission for this article to be further copied/distributed or hosted elsewhere without the express permission from American Chemical Society. 
Generation of the mixture of cis- and trans-divinylcyclopropanes $\left(\mathbf{5} / \mathbf{5}^{\prime}\right)$ is rationalized due to the difference in the oxidizing agent involved. For the (pentenediyl)iron complex 4e (Scheme 3), treatment with CAN is presumed to involve single electron oxidation to afford a $17 \mathrm{e}^{-}$intermediate, which undergoes rapid reductive elimination to give the cis-divinylcyclopropane 5e. Alternatively, treatment of $\mathbf{4 e}$ with alkaline hydrogen peroxide proceeds via nucleophilic attack on coordinated $\mathrm{CO}$, and decarbonylation, to generate a $16 \mathrm{e}^{-}$intermediate. Reductive elimination from the $16 \mathrm{e}^{-}$intermediate is slower, and a competitive reaction is a $n-\sigma-n$ rearrangement that migrates the iron from one face to the opposite face of the pentenediyl ligand. Notably, the ratio of 5e:5e' produced from decomplexation with $\mathrm{H}_{2} \mathrm{O}_{2} / \mathrm{HO}^{-}$ varies depending on the reaction temperature. In summary, a synthesis of divinylcyclopropanes from (pentadienyl)iron $(1+$ ) cations has been developed. The divinylcyclopropane products undergo Cope rearrangement to afford cycloheptadienes. The overall yields for this 4-step transformation (ca. 38-61\%) are comparable to other literature methods and preparation of enantiomerically pure cycloheptadienes has been demonstrated. Applications of this methodology to the synthesis of hydroazulene containing natural products will be reported in due course. 


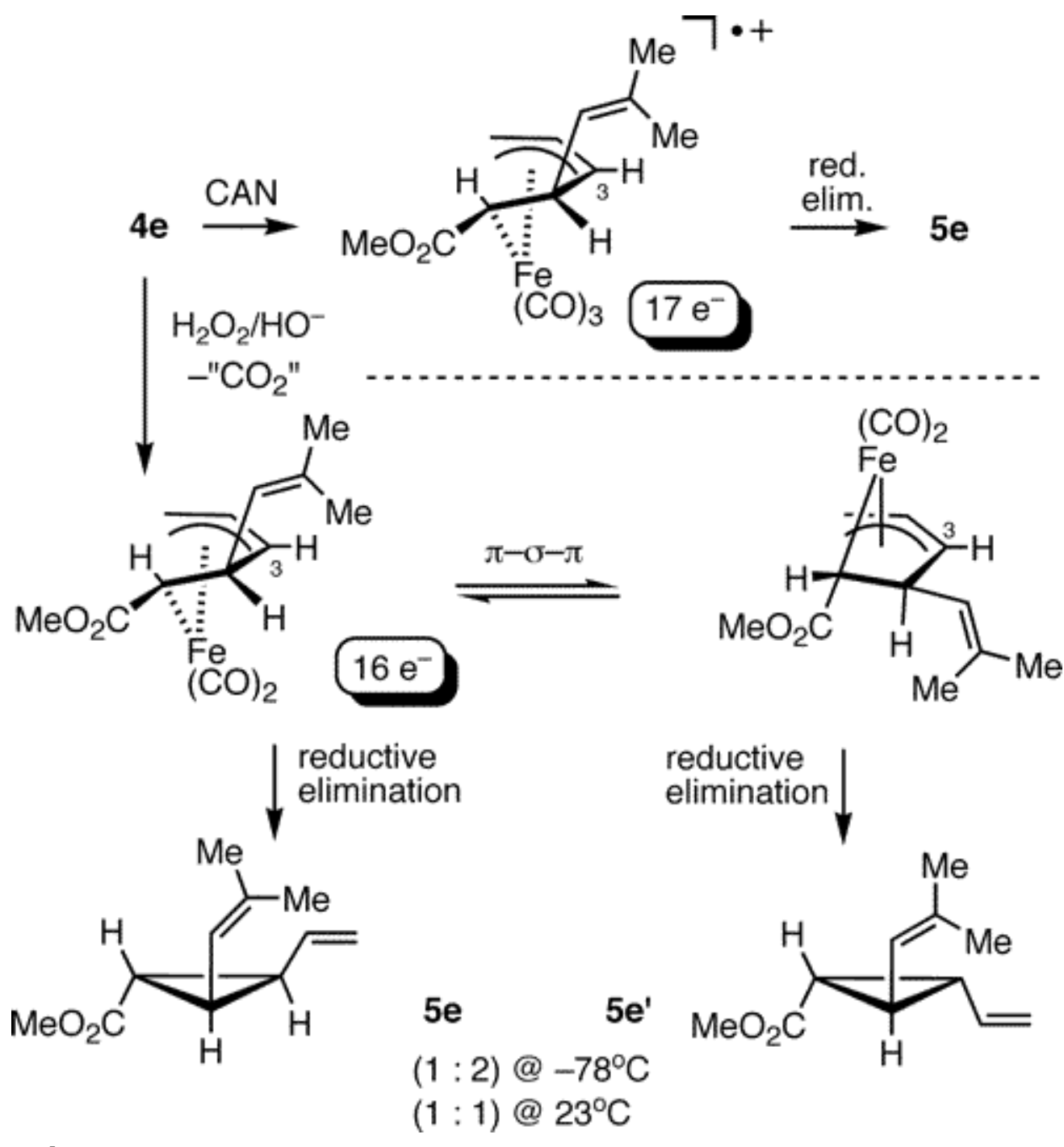

\section{Scheme 4}

\section{Acknowledgment}

The author acknowledge financial support from the National Science Foundation (CHE-0415771). The authors thank Ms. Julie Lukesh for preparation of the precursor to $(1 R)-3$.

\section{References}

${ }^{1}$ (a) Brown, J. M.; Golding, B. T.; Stofko, J. J., Jr. J. Chem. Soc., Chem. Commun. 1973, 319-320. (b) Arai, M.; Crawford, R. J. Can. J. Chem. 1972, 50, 2158-2162. (c) Hudlicky, T.; Fan, R.; Reed, J. W.; Gadamasetti, K. G. In Organic Reactions; Paquette, L. A., Editor-in-

Organic Letters, Vol 7, No. 10 (May 12, 2005): pg. 2047-2049. DOI. This article is @ American Chemical Society and permission has been granted for this version to appear in e-Publications@Marquette. American Chemical Society does not grant permission for this article to be further copied/distributed or hosted elsewhere without the express permission from American Chemical Society. 
NOT THE PUBLISHED VERSION; this is the author's final, peer-reviewed manuscript. The published version may be accessed by following the link in the citation at the bottom of the page.

Chief; John Wiley \& Sons: New York, 1992; Vol. 41, pp 1-133. (d) Piers, E. In Comprehensive Organic Synthesis; Trost, B. M., Editor-inChief; Pergammon Press: New York, 1991; Vol. 5, pp 971-998.

${ }^{2}$ Marino, J. P.; Kaneko, T. Tetrahedron Lett. 1973, 3975-3978.

${ }^{3}$ (a) Marino, J. P.; Browne, L. J. Tetrahedron Lett. 1976, 3245-3248. (b) Wender, P. A.; Filosa, M. P. J. Org. Chem. 1976, 41, 3490-3491. (c) Wender, P. A.; Hillemann, C. L.; Szymonifka, M. J. Tetrahedron Lett. 1980, 21, 2205-2208.

${ }^{4}$ (a) Davies, H. M. L.; McAfee, M. J.; Oldenburg, C. E. M. J. Org. Chem. 1989, 54, 930-936. (b) Cantrell, W. R., Jr.; Davies, H. M. L. J. Org. Chem. 1991, 56, 723-727. (c) Davies, H. M. L.; Clark, T. J.; Smith, H. D. J. Org. Chem. 1991, 56, 3817-3824. (d) Davies, H. M. L. Tetrahedron 1993, 49, 5203-5223.

5(a) Yun, Y. K.; Godula, K.; Cao, Y.; Donaldson, W. A. J. Org. Chem. 2003, 68, 901-910. (b) Lukesh, J. M.; Donaldson, W. A. Chem. Commun. 2005, 110-112. (c) Motiei, L.; Marek, I.; Gottleib, H. E.; Marks, V.; Lellouche, J.-P. Tetrahedron Lett. 2003, 44, 5909-5912.

${ }^{6}$ Pikulik, I.; Childs, R. F. Can. J. Chem. 1977, 55, 251-258.

${ }^{7}$ The higher temperature for Cope rearrangement of divinylcyclopropanes possessing a cis-alkenyl group reflects the boatlike transition state for this [3.3] sigmatropic rearrangement: Schneider, M. P.; Rau, A. J. Am. Chem. Soc. 1979, 101, 4426-4427.

${ }^{8}$ For preparation of (1R)-3 see: Tao, C.; Donaldson, W. A. J. Org. Chem. 1993, 58, 2134-2143.

\section{Supporting Information Available}

Organic Letters, Vol 7, No. 10 (May 12, 2005): pg. 2047-2049. DOI. This article is @ American Chemical Society and permission has been granted for this version to appear in e-Publications@Marquette. American Chemical Society does not grant permission for this article to be further copied/distributed or hosted elsewhere without the express permission from American Chemical Society. 


\title{
Synthesis of Cyclopropanes via Organoiron Methodology: \\ Preparation and Rearrangement of Divinylcyclopropanes
}

\author{
Nathaniel J. Wallock and William A. Donaldson*
}

Supporting Material

Experimental procedures

${ }^{1} \mathrm{H}$ NMR spectrum of $9 \mathbf{a}$

${ }^{13} \mathrm{C}$ NMR spectrum of 9 a

${ }^{1} \mathrm{H}$ NMR spectrum of $\mathbf{5 b}$

${ }^{13} \mathrm{C}$ NMR spectrum of $\mathbf{5 b}$

${ }^{13} \mathrm{C}$ NMR spectrum of $\mathbf{8 b}$

${ }^{1} \mathrm{H}$ NMR spectrum of $9 \mathbf{b}$

${ }^{13} \mathrm{C}$ NMR spectrum of $\mathbf{9 b}$

${ }^{1} \mathrm{H}$ NMR spectrum of $9 \mathrm{c}$

${ }^{13} \mathrm{C}$ NMR spectrum of $9 \mathrm{c}$

${ }^{1} \mathrm{H}$ NMR spectrum of $9 \mathbf{d}$

${ }^{13} \mathrm{C}$ NMR spectrum of $9 d$

${ }^{1} \mathrm{H}$ NMR spectrum of $\mathbf{5 e}$

${ }^{13} \mathrm{C}$ NMR spectrum of $\mathbf{5 e}$

${ }^{1} \mathrm{H}$ NMR spectrum of $9 \mathbf{e}$

${ }^{13} \mathrm{C}$ NMR spectrum of $9 \mathbf{e}$

${ }^{1} \mathrm{H}$ NMR spectrum of $9 \mathbf{f}$

${ }^{13} \mathrm{C}$ NMR spectrum of $9 \mathbf{f}$
S1-S11

S12

$\mathrm{S} 13$

S14

S15

$\mathrm{S} 16$

S17

S18

S19

S20

$\mathrm{S} 21$

$\mathrm{S} 22$

$\mathrm{S} 23$

S24

S25

S26

S27

S28

\section{Experimental Section ${ }^{1}$}

Reaction of $( \pm)-3$ with vinyl Grignard: To a stirring mixture of $r a c-3^{2}(1.640 \mathrm{~g}, 4.000 \mathrm{mmol})$ in anhydrous $\mathrm{CH}_{2} \mathrm{Cl}_{2}(40 \mathrm{~mL})$ under nitrogen at $-70{ }^{\circ} \mathrm{C}$, was added a solution of vinylmagnesium chloride in THF $(3.75 \mathrm{~mL}, 1.6 \mathrm{M}, 6.0 \mathrm{mmol})$. The dark reaction mixture was stirred for $1 \mathrm{~h}$, quenched with saturated aqueous $\mathrm{NH}_{4} \mathrm{Cl}(5 \mathrm{~mL})$, and warmed to room temperature. The mixture was poured onto water $(25 \mathrm{~mL})$, the layers were separated, and the aqueous phase extracted with $\mathrm{CH}_{2} \mathrm{Cl}_{2}(2 \times 20 \mathrm{~mL})$. The combined organic phases were dried $\left(\mathrm{MgSO}_{4}\right)$, filtered through a short 
bed of $\mathrm{SiO}_{2}$ and concentrated. Immediate column chromatography $\left(\mathrm{SiO}_{2}\right.$, hexanes-ethyl acetate $=40: 1)$ afforded rac-4a $(0.659 \mathrm{~g}, 2.26 \mathrm{mmol}, 56 \%)$ as an orange oil that crystallized upon cooling. mp 36-38 ${ }^{\circ} \mathrm{C}$; IR (KBr) 3090, 2955, 2066, 1992, 1694, $1165 \mathrm{~cm}^{-1} ;{ }^{1} \mathrm{H}$ NMR $\left(\mathrm{CDCl}_{3}\right) \delta$ 0.24 (d, $J=8.5 \mathrm{~Hz}, 1 \mathrm{H}), 2.39$ (ddd, $J=0.9,2.3,12.2 \mathrm{~Hz}, 1 \mathrm{H}), 3.55$ (ddd, $J=1.5,2.3,8.4 \mathrm{~Hz}$, $1 \mathrm{H}), 3.69(\mathrm{~s}, 3 \mathrm{H}), 3.71-3.82(\mathrm{~m}, 1 \mathrm{H}), 4.47$ (dddd, $J=1.2,1.2,7.0,7.6 \mathrm{~Hz}, 1 \mathrm{H}), 4.67$ (dddd, $J=$ $0.5,6.7,8.5,12.2 \mathrm{~Hz}, 1 \mathrm{H}), 4.77-4.81(\mathrm{~m}, 1 \mathrm{H}), 4.82-4.85(\mathrm{~m}, 1 \mathrm{H}), 5.38$ (ddd, $J=5.4,10.1,17.5$ $\mathrm{Hz}, 1 \mathrm{H}) ;{ }^{13} \mathrm{C} \mathrm{NMR}\left(\mathrm{CDCl}_{3}\right) \delta 11.4,41.9,51.7,54.4,63.5,98.2,112.7,141.2,180.5,203.8$, 210.3, 210.7. Anal. Calcd for $\mathrm{C}_{12} \mathrm{H}_{12} \mathrm{FeO}_{5}$ : C, 49.35; $\mathrm{H}, 4.14$. Found: $\mathrm{C}, 49.55 ; \mathrm{H}, 4.19$. Reaction of $r a c-3$ with cis-1-propenyl Grignard: The reaction of $\mathrm{rac}-3$ (1.64 g, $4.00 \mathrm{mmol})$ in anhydrous $\mathrm{CH}_{2} \mathrm{Cl}_{2}(40 \mathrm{~mL})$ with cis-1-propenylmagnesium bromide $(6.0 \mathrm{~mL}, 1.0 \underline{\mathrm{M}}$ in THF, freshly prepared from cis-1-bromo-1-propene) was carried out in a fashion similar to the preparation of $\mathbf{4 a}$. Column chromatography $\left(\mathrm{SiO}_{2}\right.$, hexanes-ethyl acetate $\left.=40: 1\right)$ afforded $\mathrm{rac}-\mathbf{4} \mathbf{b}$ $(0.887 \mathrm{~g}, 2.90 \mathrm{mmol}, 73 \%)$ as a crystalline orange solid. mp 56-59 ${ }^{\circ} \mathrm{C}$; IR (KBr) 3009, 2953 , 2065, 2003, 1977, 1688, $1163 \mathrm{~cm}^{-1} ;{ }^{1} \mathrm{H}$ NMR $\left(\mathrm{CDCl}_{3}\right) \delta 0.09(\mathrm{~d}, J=8.1 \mathrm{~Hz}, 1 \mathrm{H}), 1.54(\mathrm{dd}, J=$ $1.8,7.0 \mathrm{~Hz}, 3 \mathrm{H}), 2.44-2.50(\mathrm{~m}, 1 \mathrm{H}), 3.57-3.63(\mathrm{~m}, 1 \mathrm{H}), 3.68(\mathrm{~s}, 3 \mathrm{H}), 3.94-4.05(\mathrm{~m}, 1 \mathrm{H}), 4.48-$ $4.61(\mathrm{~m}, 2 \mathrm{H}), 4.81-4.91(\mathrm{~m}, 1 \mathrm{H}), 5.05-5.17(\mathrm{~m}, 1 \mathrm{H}) ;{ }^{13} \mathrm{C} \mathrm{NMR}\left(\mathrm{CDCl}_{3}\right)$ \& 13.4, 13.7, 36.9, 51.6, 54.5, 65.6, 97.3, 123.0, 135.9, 180.5, 203.9, 210.7, 210.8. Anal. Caled for $\mathrm{C}_{13} \mathrm{H}_{14} \mathrm{FeO}_{5}$ : C, 51.01; H, 4.61. Found: C, 50.89; H, 4.61 .

Reaction of (1R)-3 with cis-1-propenyl Grignard: The reaction of $(1 R)-3(1.51 \mathrm{~g}, 3.68 \mathrm{mmol})$ with cis-1-propenylmagnesium bromide was carried out in a fashion similar to the reaction of rac-3 with cis-1-propenylmagnesium bromide. Column chromatography $\left(\mathrm{SiO}_{2}\right.$, hexanes-ethyl acetate $=40: 1)$ afforded $(+)-4 \mathbf{b}(0.800 \mathrm{~g}, 2.61 \mathrm{mmol}, 71 \%)$ as an orange crystalline solid. $[\alpha]_{\mathrm{D}}{ }^{20}$ $=+589\left(\mathrm{c}=0.248, \mathrm{CHCl}_{3}\right) ; \mathrm{mp} 44-47^{\circ} \mathrm{C}$. The ${ }^{1} \mathrm{H}$ NMR spectrum of $(+)-4 \mathbf{b}$ was identical to that 
of rac-4b. Analysis by ${ }^{1} \mathrm{H}$ NMR spectroscopy in the presence of a chiral shift reagent $[(+)-$ $\left.\mathrm{Eu}(\mathrm{hfc})_{3}, \mathrm{CDCl}_{3}\right]$ indicated that the product was $>95 \%$ ee.

Reaction of ( \pm )-3 with isopropenyl Grignard (4c): The reaction of $\mathrm{rac}-\mathbf{3}(1.640 \mathrm{~g}, 4.000$ mmol) in anhydrous $\mathrm{CH}_{2} \mathrm{Cl}_{2}(40 \mathrm{~mL})$ with isopropenylmagnesium bromide ( $0.5 \underline{\mathrm{M}}$ in THF) was carried out in a fashion similar to the preparation of 4a. Immediate column chromatography $\left(\mathrm{SiO}_{2}\right.$, hexanes-ethyl acetate $\left.=30: 1\right)$ afforded $4 \mathbf{c}(0.631 \mathrm{~g}, 2.06 \mathrm{mmol}, 52 \%)$ as an orange oil which crystallized on standing. mp 46-48 ${ }^{\circ} \mathrm{C}$; IR (KBr) 3078, 2950, 2066, 2009, 1976, 1690 , $1159 \mathrm{~cm}^{-1} ;{ }^{1} \mathrm{H} \mathrm{NMR}\left(\mathrm{CDCl}_{3}\right) \delta 0.27$ (d, $\left.J=9.0 \mathrm{~Hz}, 1 \mathrm{H}\right), 1.50$ (br s, 3H), 2.27 (ddd, $J=1.0,2.2$, $12.0 \mathrm{~Hz}, 1 \mathrm{H}), 3.50(\mathrm{ddd}, J=1.5,2.2,8.5 \mathrm{~Hz}, 1 \mathrm{H}), 3.58-3.67(\mathrm{~m}, 1 \mathrm{H}), 3.70(\mathrm{~s}, 3 \mathrm{H}), 4.43-4.49(\mathrm{~m}$, 1H), 4.54-4.57 (m, 1H), 4.59-4.62 (m, 1H), 4.74 (dddd, $J=0.5,7.0,8.3,12.1 \mathrm{~Hz}, 1 \mathrm{H}) ;{ }^{13} \mathrm{C}$ NMR $\left(\mathrm{CDCl}_{3}\right) \delta$ 12.7, 19.6, 45.2, 51.7, 54.5, 64.0, 98.4, 108.8, 147.4, 180.8, 204.0, 210.2, 210.8. Anal. Calcd for $\mathrm{C}_{13} \mathrm{H}_{14} \mathrm{FeO}_{5}$ : C, 51.01; H, 4.61. Found: C, 50.57; H, 4.58 .

Reaction of $\mathrm{rac}-3$ with $\alpha$-styryl Grignard (4d): The reaction of $\mathrm{rac}-3(1.64 \mathrm{~g}, 4.00 \mathrm{mmol})$ in anhydrous $\mathrm{CH}_{2} \mathrm{Cl}_{2}(40 \mathrm{~mL})$ with $\alpha$-styrylmagnesium bromide (1.0 $\underline{\mathrm{M}}$ in THF, $6.0 \mathrm{~mL}, 6.0 \mathrm{mmol}$, freshly prepared from $\alpha$-bromostyrene) was carried out in a fashion similar to the preparation of 4a. Column chromatography $\left(\mathrm{SiO}_{2}\right.$, hexanes-ethyl acetate gradient $\left.=40: 1 \rightarrow 20: 1\right)$ gave $\mathbf{4 d}$ $(0.719 \mathrm{~g}, 1.95 \mathrm{mmol}, 49 \%)$ as a yellow-orange crystalline solid. mp 90-93 ${ }^{\circ} \mathrm{C}$; $\mathrm{IR}(\mathrm{KBr}) 3029$, $2948,2065,1994,1684,1435,1227,1163,908,777 \mathrm{~cm}^{-1} ;{ }^{1} \mathrm{H}$ NMR $\left(\mathrm{CDCl}_{3}\right) \delta 0.26(\mathrm{~d}, J=8.5$ $\mathrm{Hz}, 1 \mathrm{H}), 2.26$ (ddd, $J=0.9,2.4,12.0 \mathrm{~Hz}, 1 \mathrm{H}), 3.46(\mathrm{ddd}, J=1.5,2.4,8.3 \mathrm{~Hz}, 1 \mathrm{H}), 3.61(\mathrm{~s}, 3 \mathrm{H})$, 4.27-4.36 (m, 1H), 4.51-4.58 (m, 1H), 4.72 (dddd, $J=0.6,6.7,8.5,12.1 \mathrm{~Hz}, 1 \mathrm{H}), 4.93$ (dd, $J=$ $0.9,2.0 \mathrm{~Hz}, 1 \mathrm{H}), 5.07(\mathrm{dd}, J=0.9,2.0 \mathrm{~Hz}, 1 \mathrm{H}), 7.19-7.30(\mathrm{~m}, 5 \mathrm{H}) ;{ }^{13} \mathrm{C} \mathrm{NMR}\left(\mathrm{CDCl}_{3}\right) \delta 12.1$, $42.4,51.6,54.2,63.5,97.9,111.7,127.3,127.7,128.3,139.3,152.2,180.7,204.0,210.0,210.8$. Anal. Calcd for $\mathrm{C}_{18} \mathrm{H}_{16} \mathrm{FeO}_{5}$ : C, 58.72; H, 4.38. Found: C, 58.83; H, 4.53 . 
Reaction of $\mathrm{rac}$-3 with 2-methyl-1-propenyl Grignard (4e): The reaction of $\mathrm{rac}-3$ (1.640 g, $4.000 \mathrm{mmol})$ in anhydrous $\mathrm{CH}_{2} \mathrm{Cl}_{2}(40 \mathrm{~mL})$ 2-methyl-1-propenylmagnesium bromide ( $0.5 \underline{\mathrm{M}}$ in THF, $12.0 \mathrm{~mL}, 6.0 \mathrm{mmol}$ ) was carried out in a fashion similar to the preparation of $4 \mathbf{a}$. Immediate column chromatography $\left(\mathrm{SiO}_{2}\right.$, hexanes-ethyl acetate $\left.=40: 1\right)$ afforded $4 \mathbf{e}(0.904 \mathrm{~g}$, $2.82 \mathrm{mmol}, 71 \%$ ) as a yellow crystalline solid. $\mathrm{mp} 64-65^{\circ} \mathrm{C}$; IR (KBr) 2983, 2948, 2910, 2855, 2058, 2000, 1943, 1692, 1432, 1365, 1160, 890, $845 \mathrm{~cm}^{-1} ;{ }^{1} \mathrm{H}$ NMR $\left(\mathrm{CDCl}_{3}\right) \delta 0.08(\mathrm{~d}, J=8.1$ $\mathrm{Hz}, 1 \mathrm{H}), 1.54(\mathrm{~s}, 3 \mathrm{H}), 1.55(\mathrm{~s}, 3 \mathrm{H}), 2.42-2.51(\mathrm{~m}, 1 \mathrm{H}) 3.55-3.61(\mathrm{~m}, 1 \mathrm{H}), 3.67(\mathrm{~s}, 3 \mathrm{H}), 3.87$ (br q, $J \approx 8.1 \mathrm{~Hz}, 1 \mathrm{H}), 4.47-4.64(\mathrm{~m}, 3 \mathrm{H}) ;{ }^{13} \mathrm{C} \mathrm{NMR}\left(\mathrm{CDCl}_{3}\right) \delta 14.2,18.6,25.7,38.0,51.6,54.4$, 66.4, 97.1, 130.6, 131.1, 180.6, 204.0, 210.7, 211.0. Anal. Calcd for $\mathrm{C}_{14} \mathrm{H}_{16} \mathrm{FeO}_{5}$ : C, 52.53; H, 5.03. Found: $\mathrm{C}, 52.35 ; \mathrm{H}, 5.24$.

Reaction of rac-3 with 1-cyclopentenyl Grignard (4f): The reaction of rac-3 (1.64 g, 4.00 mmol) in anhydrous $\mathrm{CH}_{2} \mathrm{Cl}_{2}(40 \mathrm{~mL})$ with 1-cyclopentenylmagnesium bromide (1.0 $\underline{\mathrm{M}}$ in $\mathrm{THF}$, freshly prepared from 1-bromocyclopentene) was carried out in a fashion similar to the preparation of $\mathbf{4 a}$. Immediate column chromatography $\left(\mathrm{SiO}_{2}\right.$, hexanes-ethyl acetate $\left.=40: 1\right)$ afforded rac-4f $(0.661 \mathrm{~g}, 1.99 \mathrm{mmol}, 50 \%)$ as a yellow crystalline solid. $\mathrm{mp} 86-94{ }^{\circ} \mathrm{C}$; IR (KBr) 2951, 2846, 2067, 2009, 1975, 1690, $1161 \mathrm{~cm}^{-1} ;{ }^{1} \mathrm{H}$ NMR $\left(\mathrm{CDCl}_{3}\right) \delta 0.29(\mathrm{~d}, J=8.8 \mathrm{~Hz}, 1 \mathrm{H})$, $1.67-1.82(\mathrm{~m}, 2 \mathrm{H}), 1.93-2.11(\mathrm{~m}, 2 \mathrm{H}), 2.11-2.24(\mathrm{~m}, 2 \mathrm{H}), 2.39$ (dd, $J=1.9,12.0 \mathrm{~Hz}, 1 \mathrm{H}), 3.522$ (ddd, $J=1.7,2.0,8.4 \mathrm{~Hz}, 1 \mathrm{H}), 3.64-3.75(\mathrm{~m}, 1 \mathrm{H}$ and $\mathrm{s}, 3 \mathrm{H}), 4.46-4.54(\mathrm{~m}, 2 \mathrm{H}), 4.65$ (ddd, $J=$ 6.9, 8.4, $12.0 \mathrm{~Hz}, 1 \mathrm{H}), 5.16$ (pseudo $\mathrm{h}, J=2.1 \mathrm{~Hz}, 1 \mathrm{H}) ;{ }^{13} \mathrm{C} \mathrm{NMR}\left(\mathrm{CDCl}_{3}\right) \delta$ 12.0, 23.5, 32.11, $32.14,40.6,51.7,54.5,64.3,98.2,123.0,147.2,180.8,204.0,210.5,210.9$. Anal. Calcd for $\mathrm{C}_{15} \mathrm{H}_{16} \mathrm{O}_{5} \mathrm{Fe}: \mathrm{C}, 54.24 ; \mathrm{H}, 4.86$. Found: $\mathrm{C}, 54.33 ; \mathrm{H}, 4.93$.

Oxidative decomplexation of 4a with CAN (Conditions A): To a stirring solution of 4a ( 0.595 $\mathrm{g}, 1.71 \mathrm{mmol})$ in absolute methanol $(20 \mathrm{~mL})$ was added in portions CAN $(6 \times 1.13 \mathrm{~g}, 99 \%, 12.2$ 
$\mathrm{mmol}$ ) over a period of $25 \mathrm{~min}$. After stirring for $10 \mathrm{~min}$ after the last addition, the red mixture was poured onto brine $(25 \mathrm{~mL})$ and extracted with ethyl acetate $(3 \times 25 \mathrm{~mL})$. The combined extracts were washed sequentially with: water $(3 \times 25 \mathrm{~mL})$, saturated aqueous sodium bicarbonate $(25 \mathrm{~mL})$ and brine $(25 \mathrm{~mL})$. The organic phase was then dried $\left(\mathrm{MgSO}_{4}\right)$. Analysis of an aliquot by ${ }^{1} \mathrm{H}$ NMR spectroscopy typically indicated the presence of kinetically unstable cyclopropane 5a along with varying amounts of the Cope rearrangement product 3methoxycarbonyl-1,4-cycloheptadiene. The organic phase (i.e. the ethyl acetate extracts) was heated in an oil bath at $55-60^{\circ} \mathrm{C}$ for $45 \mathrm{~min}$, cooled to room temperature, and carefully concentrated at $20^{\circ} \mathrm{C}$. Column chromatography $\left(\mathrm{SiO}_{2}\right.$, hexanes-ethyl acetate $\left.=20: 1\right)$ gave 3methoxycarbonyl-1,4-cycloheptadiene $(0.215 \mathrm{~g}, 1.41 \mathrm{mmol}, 69 \%)$ as a volatile colorless oil. The ${ }^{1} \mathrm{H}$ NMR spectrum was identical with the literature ${ }^{3}$ spectral data.

5a: ${ }^{1} \mathrm{H} \mathrm{NMR}\left(\mathrm{CDCl}_{3}\right) \delta 1.86(\mathrm{t}, J=4.9 \mathrm{~Hz}, 1 \mathrm{H}), 2.27-2.35(\mathrm{~m}, 2 \mathrm{H}), 3.70(\mathrm{~s}, 3 \mathrm{H}), 5.12(\mathrm{dd}, J=$ $1.7,10.3 \mathrm{~Hz}, 2 \mathrm{H}), 5.24(\mathrm{ddd}, J=0.6,1.8,17.0 \mathrm{~Hz}, 2 \mathrm{H}), 5.49-5.62(\mathrm{~m}, 2 \mathrm{H}) ;{ }^{13} \mathrm{C} \mathrm{NMR}\left(\mathrm{CDCl}_{3}\right) \delta$ $28.2,31.8,52.2,117.4,133.8,173.1$.

3-methoxycarbonyl-1,4-cycloheptadiene: IR (neat) 3028, 2951, 2907, 2836, 1743, 1644, 1435, 1266, 1171, 1030, 822, 796; ${ }^{1} \mathrm{H}$ NMR $\left(\mathrm{CDCl}_{3}\right) \delta 2.13-2.39$ (m, 4H), 3.74 (s, 3H), 4.17-4.25 (m, $1 \mathrm{H}), 5.77-5.93(\mathrm{~m}, 4 \mathrm{H}) ;{ }^{13} \mathrm{C} \mathrm{NMR}\left(\mathrm{CDCl}_{3}\right) \delta 26.2,44.8,52.5,127.1,132.4,173.8$.

\section{General Procedure for Oxidative decomplexation (CAN)/reduction/Cope rearrangement} sequence. Cyclohepta-2,6-dienylmethanol (9a): To a stirring solution of $4 \mathbf{a}(0.500 \mathrm{~g}, 1.71$ $\mathrm{mmol})$ in absolute methanol $(17 \mathrm{~mL})$ was added in portions CAN $(6 \times 0.95 \mathrm{~g}, 99 \%, 10.3 \mathrm{mmol})$ over a period of $14 \mathrm{~min}$. Shortly after the last addition and cessation of effervescence, the red mixture was poured onto brine $(20 \mathrm{~mL})$ and extracted with ethyl acetate $(4 \times 20 \mathrm{~mL})$. The combined extracts were washed sequentially with: water $(3 \times 20 \mathrm{~mL})$, saturated aqueous sodium 
bicarbonate $(20 \mathrm{~mL})$ and brine $(20 \mathrm{~mL})$. The organic phase was dried $\left(\mathrm{MgSO}_{4}\right)$ and carefully concentrated at $20^{\circ} \mathrm{C}$ to give a volatile yellow oil. The oil was dissolved in ether $(\sim 1.0 \mathrm{~mL})$ and added dropwise to a stirring solution of $\mathrm{LiAlH}_{4}$ in ether $(3.0 \mathrm{~mL}, 1.0 \mathrm{M}, 3.0 \mathrm{mmol})$ at $0{ }^{\circ} \mathrm{C}$. Additional ether $(\sim 2.0 \mathrm{~mL})$ was used to insure a quantitative transfer of the crude $5 \mathbf{a}$. The solution was stirred at $0{ }^{\circ} \mathrm{C}$ for $3 \mathrm{~h}$, then quenched with saturated aqueous sodium bicarbonate ( 5 $\mathrm{mL})$. After warming to room temperature and diluting with $2 \mathrm{M} \mathrm{NaOH}(10 \mathrm{~mL})$, the mixture was extracted with ether $(4 \times 15 \mathrm{~mL})$. The combined extracts were dried $\left(\mathrm{MgSO}_{4}\right)$ and concentrated to give an oil. Analysis of this oil by ${ }^{1} \mathrm{H}$ NMR spectroscopy did not indicate the presence of intermediate $8 \mathbf{a}$. Column chromatography $\left(\mathrm{SiO}_{2}\right.$, hexanes-ethyl acetate $\left.=4: 1\right)$ of the crude material provided 9a as a colorless oil $(0.177 \mathrm{~g}, 1.43 \mathrm{mmol}, 83 \%)$. IR (neat) 3346 (br), 3014, 2906, 1646, 1449, 1430, 1033, 817, 784, $736 \mathrm{~cm}^{-1}$; ${ }^{1} \mathrm{H} \mathrm{NMR}\left(\mathrm{CDCl}_{3}\right) \delta 1.52$ (br s, $\left.1 \mathrm{H}\right)$, 2.12-2.25 (m, 2H), 2.27-2.40 (m, 2H), 3.29-3.40 (m, 1H), 3.67 (app. d, $J=6.0 \mathrm{~Hz}, 2 \mathrm{H}$ ), 5.51$5.59(\mathrm{~m}, 2 \mathrm{H}), 5.84-5.93(\mathrm{~m}, 2 \mathrm{H}) ;{ }^{13} \mathrm{C} \mathrm{NMR}\left(\mathrm{CDCl}_{3}\right) \delta 26.9,42.3,67.1,130.2,132.3$. GC/MS $m / z$ 124. Anal. Calcd for $\mathrm{C}_{8} \mathrm{H}_{12} \mathrm{O} \cdot 0.3 \mathrm{H}_{2} \mathrm{O}:$ C, $74.15 ; \mathrm{H}, 9.80$. Found: $\mathrm{C}, 74.05 ; \mathrm{H}, 9.66$. trans-(4-Methylcyclohepta-2,6-dienyl)methanol ( $r a c-9 b)$ : The decomplexation of rac-4b $(0.295 \mathrm{~g}, 0.801 \mathrm{mmol})$ with $\mathrm{CAN} / \mathrm{MeOH}$ was carried out in a fashion similar to the above procedure, to give crude $r a c-5 b$ as a volatile yellow oil. The crude divinylcyclopropane carboxylate was reduced with $\mathrm{LiAlH}_{4} /$ ether, in a fashion similar to that above, to give $\mathrm{rac}-\mathbf{8 b}$ as a colorless oil. The crude divinylcyclopropylmethanol was dissolved in toluene $(10 \mathrm{~mL})$ and heated in a sealed reaction tube at $115-125^{\circ} \mathrm{C}$ for $90 \mathrm{~min}$. After cooling to ambient temperature, purification by column chromatography $\left(\mathrm{SiO}_{2}\right.$, hexanes-ethyl acetate gradient $\left.=10: 1 \rightarrow 4: 1\right)$ gave rac-9b as a colorless oil ( $0.155 \mathrm{~g}, 1.12 \mathrm{mmol}, 81 \%)$. IR (neat) 3334, 3009, 2955, 2928 , $2871,1655,1456,1372,1026,828,775,731,674 \mathrm{~cm}^{-1} ;{ }^{1} \mathrm{H} \mathrm{NMR}\left(\mathrm{CDCl}_{3}\right) \delta 1.04(\mathrm{~d}, J=7.0 \mathrm{~Hz}$, 
$3 \mathrm{H}), 1.50$ (br s, 1H), 2.07-2.29 (m, 2H), 2.39-2.53 (m, 1H), 3.19-3.29 (m, 1H), 3.68 (app. d, $J \approx$ $6.0 \mathrm{~Hz}, 2 \mathrm{H}$ ), 5.43 (dddd, $J=1.4,2.1,4.1,11.8 \mathrm{~Hz}, 1 \mathrm{H}), 5.59-5.68$ (m, $2 \mathrm{H}), 5.91$ (dddd, $J=2.3$, 5.3, 7.3, $11.1 \mathrm{~Hz}, 1 \mathrm{H}) ;{ }^{13} \mathrm{C} \mathrm{NMR}\left(\mathrm{CDCl}_{3}\right) \delta 22.9,32.6,34.8,42.5,66.9,127.3,131.1,131.2$, 138.8; $\mathrm{GC} / \mathrm{MS} m / z$ 138. Anal. Calcd for $\mathrm{C}_{9} \mathrm{H}_{14} \mathrm{O} \cdot 0.2 \mathrm{H}_{2} \mathrm{O}: \mathrm{C}, 76.23 ; \mathrm{H}, 10.23$. Found: $\mathrm{C}$, $76.33 ; \mathrm{H}, 10.12$.

For the purposes of characterization, the crude divinylcyclopropane carboxylate could be purified by column chromatography $\left(\mathrm{SiO}_{2}\right.$, hexanes-ethyl acetate $\left.=20: 1\right)$ to give $\mathrm{rac}-\mathbf{5} \mathbf{b}(75 \%)$ as a pale yellow oil). 5b: IR (neat) 3085, 3025, 2952, 2857, 1728, 1637, 1441, 1284, 1211, 1168, $912,810 \mathrm{~cm}^{-1} ;{ }^{1} \mathrm{H} \mathrm{NMR}\left(\mathrm{CDCl}_{3}\right) \delta 1.72(\mathrm{dd}, J=1.8,6.8 \mathrm{~Hz}, 3 \mathrm{H}), 1.75(\mathrm{dd}, J=4.8,4.8 \mathrm{~Hz}, 1 \mathrm{H})$, 2.27-2.36 (m, 1H), 2.43 (ddt, $J=1.2,4.9,9.2 \mathrm{~Hz}, 1 \mathrm{H}), 3.70(\mathrm{~s}, 3 \mathrm{H}), 5.05-5.15(\mathrm{~m}, 2 \mathrm{H}), 5.23$ (ddd, $J=0.6,1.8,17.0 \mathrm{~Hz}, 1 \mathrm{H}), 5.47-5.68(\mathrm{~m}, 2 \mathrm{H}),{ }^{13} \mathrm{C} \mathrm{NMR}\left(\mathrm{CDCl}_{3}\right) \delta 13.7,26.8,29.2,31.8$, 52.2, 117.2, 125.6, 127.9, 134.3, 173.4. Anal. Calcd for $\mathrm{C}_{10} \mathrm{H}_{14} \mathrm{O}_{2} \cdot 0.25 \mathrm{H}_{2} \mathrm{O}$ : C, $70.35 ; \mathrm{H}, 8.56$. Found: C, $70.24 ; \mathrm{H}, 8.42$.

Similarly, the kinetically stable divinylcyclopropyl methanol could be obtained by chromatographic purification $\left(\mathrm{SiO}_{2}\right.$, hexanes-ethyl acetate $\left.=20: 1\right)$ of the crude material, giving rac-8b (73\%) as a volatile pale yellow oil. 8b: ${ }^{1} \mathrm{H}$ NMR $\left(\mathrm{CDCl}_{3}\right) \delta 1.23-1.34(\mathrm{~m}, 1 \mathrm{H}), 1.63-1.72$ (overlapped m, 1H), 1.65 (br s, 1H), 1.70 (dd, $J=1.7,6.8 \mathrm{~Hz}, 3 \mathrm{H}), 1.73-1.82$ (m, 1H), 3.60 (app. d, $J=6.7 \mathrm{~Hz}, 2 \mathrm{H}), 5.01(\mathrm{ddd}, J=0.6,1.8,10.3 \mathrm{~Hz}, 1 \mathrm{H}), 5.07-5.17(\mathrm{~m}, 2 \mathrm{H}), 5.47-5.62(\mathrm{~m}, 2 \mathrm{H})$; ${ }^{13} \mathrm{C} \mathrm{NMR}\left(\mathrm{CDCl}_{3}\right) \delta 13.6,22.6,27.8,30.8,66.0,115.0,125.6,128.0,136.8$. ((1S,4S)-4-methylcyclohepta-2,6-dienyl)methanol ((-)-9b): The decomplexation of (+)-4b $(0.475 \mathrm{~g}, 1.55 \mathrm{mmol}$ ) with $\mathrm{CAN} / \mathrm{MeOH}$ was carried out in a fashion similar to that for $\mathrm{rac}-\mathbf{4 b}$, to give crude (+)-5b as a volatile yellow oil. The oil was then reduced with $\mathrm{LiAlH}_{4} /$ ether in a fashion similar to that for the racemic material, to give (+)-8b as a colorless oil. The oil was 
dissolved in toluene $(10 \mathrm{~mL})$ and heated under nitrogen in a sealed reaction tube at $125^{\circ} \mathrm{C}$ for 90 min. After cooling to ambient temperature, purification by column chromatography $\left(\mathrm{SiO}_{2}\right.$, hexanes-ethyl acetate $=10: 1 \rightarrow 4: 1)$ provided $(-)-9 \mathbf{b}$ as a colorless oil $(0.178 \mathrm{~g}, 1.29 \mathrm{mmol}$, $83 \%)$. Intermediates $(+)-\mathbf{5 b}\left(83 \%, 1\right.$ step) and $(+)-\mathbf{8 b}\left(90 \%, 1\right.$ step) were isolated, purified $\left(\mathrm{SiO}_{2}\right.$, hexanes-ethyl acetate $=10: 1$ and $\mathrm{SiO}_{2}$, hexanes-ethyl acetate $=4: 1$ respectively), and characterized in separate experiments.

$(+)-5 \mathbf{b}:[\alpha]_{\mathrm{D}}^{20}=+28.2\left(\mathrm{c}=0.410, \mathrm{CHCl}_{3}\right)$. The ${ }^{1} \mathrm{H}$ NMR spectrum of $(+)-5 \mathbf{b}$ was identical with that of rac-5b. This compound was determined to be optically pure by comparison of the ${ }^{1} \mathrm{H}$ NMR spectrum $\left(\mathrm{CDCl}_{3}\right)$ in the presence of $(+)$-Eu(hfc $)_{3}$ with that of the racemic material.

$(+)-8 b:[\alpha]_{D}{ }^{20}=+89.0\left(\mathrm{c}=0.352, \mathrm{CHCl}_{3}\right)$. The ${ }^{1} \mathrm{H}$ NMR spectrum of $(+)-8 \mathbf{b}$ was identical with that of rac-8b.

$(-)-9 \mathbf{b}:[\alpha]_{\mathrm{D}}^{20}=-7.2\left(\mathrm{c}=0.448, \mathrm{CHCl}_{3}\right)$. The ${ }^{1} \mathrm{H}$ NMR spectrum of $(-)-9 \mathbf{b}$ was identical with that of rac-9b. This compound was determined to be optically pure by comparison of the ${ }^{1} \mathrm{H}$ NMR spectrum $\left(\mathrm{C}_{6} \mathrm{D}_{6}\right)$ of the $(S)$-MTPA esters derived from both (-)-9b and rac-9b. In the case of diastereomeric esters derived from rac-9b, separation of signals could be observed for the allylic methyl groups.

(3-Methylcyclohepta-2,6-dienyl)methanol (9c): Decomplexation (conditions

A)/reduction/Cope rearrangement of $4 \mathbf{c}(0.315 \mathrm{~g}, 1.03 \mathrm{mmol})$ according to the above procedure, followed by column chromatography $\left(\mathrm{SiO}_{2}\right.$, hexanes-ethyl acetate $\left.=4: 1\right)$ of the crude material provided $9 \mathbf{c}$ as a colorless oil ( $0.116 \mathrm{~g}, 0.839 \mathrm{mmol}, 82 \%)$. IR (neat) 3342, 3011, 2910, 1652, 1445, 1375, 1078, 1023, $811 \mathrm{~cm}^{-1} ;{ }^{1} \mathrm{H}$ NMR $\left(\mathrm{CDCl}_{3}\right) \delta 1.49$ (br s, $\left.1 \mathrm{H}\right), 1.76(\mathrm{t}, J=1.6 \mathrm{~Hz}, 3 \mathrm{H})$, 1.99-2.10 (m, 1H), 2.10-2.35 (m, 2H), 2.36-2.48 (m, 1H), 3.26-3.36 (m, 1H), 3.65 (app. d, $J=$ $6.3 \mathrm{~Hz}, 2 \mathrm{H}$ ), $5.33-5.38$ (m, $1 \mathrm{H}), 5.54$ (qdd, $J=1.3,3.9,11.3 \mathrm{~Hz}, 1 \mathrm{H}$ ), 5.80 (ddddd, $J=0.6,2.4$, 
5.0, 5.5, $11.2 \mathrm{~Hz}, 1 \mathrm{H}) ;{ }^{13} \mathrm{C} \mathrm{NMR}\left(\mathrm{CDCl}_{3}\right) \delta 26.0,26.1,31.7,40.8,67.3,124.6,130.2,131.5$, 140.0. GC/MS $m / z$ 138. Anal. Calcd for $\mathrm{C}_{9} \mathrm{H}_{14} \mathrm{O} \cdot 0.25 \mathrm{H}_{2} \mathrm{O}$ : C, $75.75 ; \mathrm{H}, 10.24$. Found: C, 75.73; H, 10.11.

(3-Phenylcyclohepta-2,6-dienyl)methanol (9d): Decomplexation (CAN)/reduction/Cope rearrangement of $\mathbf{4 d}(0.295 \mathrm{~g}, 0.801 \mathrm{mmol})$ according to the above procedure, followed by column chromatography $\left(\mathrm{SiO}_{2}\right.$, hexanes-ethyl acetate $\left.=4: 1\right)$ of the crude material provided $\mathbf{9 d}$ as a pale yellow oil ( $0.053 \mathrm{~g}, 0.265 \mathrm{mmol}, 33 \%$ ). IR (neat) $3352,3019,2811,1598,1494,1444$, 1081, 1028, 758, $697 \mathrm{~cm}^{-1} ;{ }^{1} \mathrm{H}$ NMR $\left(\mathrm{CDCl}_{3}\right) \delta 1.62$ (br s, $\left.1 \mathrm{H}\right), 2.22-2.48$ (m, 2H), 2.65 (qddd, $J$ $=0.8,3.5,6.5,14.7 \mathrm{~Hz}, 1 \mathrm{H}), 2.99(\operatorname{tddd}, J=1.2,3.5,11.0,14.7 \mathrm{~Hz}, 1 \mathrm{H}), 3.52-3.61(\mathrm{~m}, 1 \mathrm{H}), 3.76$ (app. d, $J \approx 6.5 \mathrm{~Hz}, 2 \mathrm{H}), 5.49-5.57$ (m, $1 \mathrm{H}), 5.75-5.84$ (m, $1 \mathrm{H}), 5.96$ (qd, $J=1.0,4.4 \mathrm{~Hz}, 1 \mathrm{H}$ ), 7.20-7.40 (m, 5H); ${ }^{13} \mathrm{C} \mathrm{NMR}\left(\mathrm{CDCl}_{3}\right) \delta 26.9,30.0,40.9,67.2,125.8,126.9,128.3,128.5,129.6$, 131.5, 143.1, 143.4; GC/MS m/z 200. Anal. Calcd for $\mathrm{C}_{14} \mathrm{H}_{16} \mathrm{O} \cdot 0.5 \mathrm{H}_{2} \mathrm{O}: \mathrm{C}, 80.35 ; \mathrm{H}, 8.19$. Found: C, 80.38; H, 7.85 .

Attempted oxidative decomplexation (CAN) of 4e. Attempted oxidative decomplexation of $4 \mathrm{e}$ in methanol gave a complex mixture of unidentifiable products. Attempted oxidative decomplexation of $4 \mathbf{e}(0.456 \mathrm{~g}, 1.42 \mathrm{mmol})$ with $\mathrm{CAN}$ using $\mathrm{CH}_{3} \mathrm{CN}$ as solvent, followed by purification by column chromatography $\left(\mathrm{SiO}_{2}\right.$, hexanes-ethyl acetate $\left.=20: 1\right)$ gave $5 \mathbf{e}(0.028 \mathrm{~g}$, $0.155 \mathrm{mmol}, 11 \%$ ) as a pale yellow, volatile oil. IR (neat) $3085,2926,2855,1730,1638,1444$, 1284, 1213, 1159, 985, $902 \mathrm{~cm}^{-1} ;{ }^{1} \mathrm{H}$ NMR $\left(\mathrm{CDCl}_{3}\right) \delta 1.69(\mathrm{dd}, J=4.8,4.8 \mathrm{~Hz}, 1 \mathrm{H}), 1.71(\mathrm{~s}$, $3 \mathrm{H}), 1.72(\mathrm{~s}, 3 \mathrm{H}), 2.23-2.37$ (m, 2H), 3.69 (s, 3H), 4.87 (qdd, $J=1.5,1.5,8.5 \mathrm{~Hz}, 1 \mathrm{H}), 5.10$ (ddd, $J=0.6,1.8,10.3 \mathrm{~Hz}, 1 \mathrm{H}), 5.22(\mathrm{ddd}, J=0.8,1.8,17.2 \mathrm{~Hz}, 1 \mathrm{H}), 5.47-5.60(\mathrm{~m}, 1 \mathrm{H}) ;{ }^{13} \mathrm{C}$ NMR $\left(\mathrm{CDCl}_{3}\right) \delta 18.8,26.0,27.8,29.3,31.8,52.1,117.0,119.7,134.7,136.4,173.6$. Exposure of 5e to excess CAN in methanol resulted in decomposition into unidentifiable products. 


\section{General Procedure for Oxidative decomplexation $\left(\mathrm{H}_{2} \mathrm{O}_{2} / \mathrm{HO}^{-}\right) /$reduction/Cope}

rearrangement sequence. (4,4-Dimethylcyclohepta-2,6-dienyl)methanol (9e): To a stirring solution of complex $4 \mathbf{e}(0.780 \mathrm{~g}, 2.44 \mathrm{mmol})$ in absolute methanol $(50 \mathrm{~mL})$ and $30 \%$ aqueous $\mathrm{H}_{2} \mathrm{O}_{2}(15 \mathrm{~mL})$ at $-78^{\circ} \mathrm{C}$ under nitrogen, was added a methanolic solution of $\mathrm{NaOH}(0.59 \mathrm{~g}, 15$ $\mathrm{mmol} \mathrm{NaOH}$ dissolved in a minimal volume of methanol). The mixture was stirred at $-78^{\circ} \mathrm{C}$ for $30 \mathrm{~min}$, the cold bath was removed, and the mixture stirred for an additional $30 \mathrm{~min}$ while warming to room temperature. During this period, the reaction bubbled and became brown. The muddy mixture was diluted with water $(50 \mathrm{~mL})$ and extracted with ether $(4 \times 50 \mathrm{~mL})$. The combined extracts were washed with water $(3 \times 50 \mathrm{~mL})$ followed by brine $(50 \mathrm{~mL})$. The organic phase was dried $\left(\mathrm{MgSO}_{4}\right)$ and concentrated to give a volatile yellow oil. The ${ }^{1} \mathrm{H}$ NMR spectrum indicated the residue to contain a mixture of cis and trans-divinylcyclopropane carboxylates $\left(\mathbf{5 e}: 5 \mathbf{e}^{\prime} \approx 1: 2.2\right)$. The crude mixture $\left(\mathbf{5 e}: 5 \mathbf{e}^{\prime}\right)$ was reduced with $\mathrm{LiAlH}_{4}$ in ether $(4.2 \mathrm{~mL}, 1.0 \mathrm{M}$, $4.2 \mathrm{mmol}$ ) at $0{ }^{\circ} \mathrm{C}$ in a fashion similar to that above to give a tan oil. Analysis of the residue by ${ }^{1} \mathrm{H}$ NMR spectroscopy indicated that it consisted of a mixture of cis and transdivinylcyclopropylmethanols $(1: 2.2)$. None of the rearrangement product was observed. The mixture of divinylcyclopropylmethanols was dissolved in mesitylene $(12 \mathrm{~mL})$ and heated under nitrogen in a sealed reaction tube at $195-200^{\circ} \mathrm{C}$ for $1 \mathrm{~h}$. After cooling to ambient temperature, purification by column chromatography $\left(\mathrm{SiO}_{2}\right.$, hexanes-ethyl acetate gradient $\left.=10: 1 \rightarrow 4: 1\right)$ provided 9e as a pale yellow oil ( $0.296 \mathrm{~g}, 1.94 \mathrm{mmol}, 80 \%)$. IR (neat) 3337 (br), 3001, 2955, $2866,1653,1469,1375,1359,1079,1031,807,746,699 \mathrm{~cm}^{-1} ;{ }^{1} \mathrm{H} \mathrm{NMR}\left(\mathrm{CDCl}_{3}\right) \delta 1.02(\mathrm{~s}, 3 \mathrm{H})$, 1.05 (s, 3H), 1.46 (br s, 1H), 2.08 (dddd, $J=1.1,1.1,6.8,14.1 \mathrm{~Hz}, 1 \mathrm{H}), 2.38$ (dd, $J=6.5,14.2$ Hz, 1H), 3.21-3.31 (m, 1H), 3.66 (app. d, $J \approx 6.1 \mathrm{~Hz}, 2 \mathrm{H}$ ), 5.28 (ddd, $J=1.3,3.3,12.0 \mathrm{~Hz}, 1 \mathrm{H}$ ), 5.46 (ddd, $J=1.3,2.6,12.0 \mathrm{~Hz}, 1 \mathrm{H}), 5.74$ (dddd, $J=1.3,1.3,4.1,10.6 \mathrm{~Hz}, 1 \mathrm{H}), 5.85$ (dtd, $J=$ 
2.0, 6.5, 10.6 Hz, 1H); ${ }^{13} \mathrm{C} \mathrm{NMR}\left(\mathrm{CDCl}_{3}\right) \delta 29.7,30.9,35.3,39.9,41.5,66.9,125.1,130.2$,

132.7, 142.2; GC/MS m/z 152. Anal. Calcd for $\mathrm{C}_{10} \mathrm{H}_{16} \mathrm{O} \cdot 0.1 \mathrm{H}_{2} \mathrm{O}$ : C, $77.97 ; \mathrm{H}, 10.60$. Found: C, 77.73; H, 10.55 .

3-Hydroxymethylene-bicyclo[5.3.0]dec-1,4-diene (9f): Decomplexation $\left(\mathrm{H}_{2} \mathrm{O}_{2}\right)$ /reduction of $\mathbf{4 f}$ $(0.657 \mathrm{~g}, 1.98 \mathrm{mmol})$ according to the above procedure, followed by Cope rearrangement in mesitylene at $210-220^{\circ} \mathrm{C}$, and purification by column chromatography $\left(\mathrm{SiO}_{2}\right.$, hexanes-ethyl acetate gradient $=10: 1 \rightarrow 4: 1)$ gave 9 f as a colorless oil ( $0.248 \mathrm{~g}, 1.51 \mathrm{mmol}, 76 \%$ for 3 steps $)$. IR (neat) 3338 (br), 3000, 2948, 2869, 1062, $1026 \mathrm{~cm}^{-1} ;{ }^{1} \mathrm{H}$ NMR $\left(\mathrm{CDCl}_{3}\right) \delta 1.24-1.36(\mathrm{~m}, 1 \mathrm{H})$, 1.48 (br s, 1H), 1.49-1.61 (m, 1H), 1.63-1.76 (m, 1H), 1.85-1.99 (m, 1H), 2.01-2.14 (m, 1H), 2.16-2.27 (m, 1H), 2.30-2.42 (m, 2H), 2.75-2.89 (m, 1H), 3.22-3.33 (m, 1H), 3.64 (pseudo dd, $J$ $=2.7,5.6,2 \mathrm{H}), 5.39-5.49(\mathrm{~m}, 2 \mathrm{H}), 5.73-5.82(\mathrm{~m}, 1 \mathrm{H}),{ }^{13} \mathrm{C} \mathrm{NMR}\left(\mathrm{CDCl}_{3}\right) \delta$ 25.6, 34.0, 34.9, $35.1,41.3,42.4,67.7,120.1,128.8,131.0,150.7$.

${ }^{1}$ For general experimental instrumentations and conditions, see: Yun, Y. K.; Godula, K.; Cao, Y.; Donaldson, W. A. J. Org. Chem. 2003, 68, 901-910.

${ }^{2}$ Tao, C.; Donaldson, W. A. J. Org. Chem. 1993, 58, 2134-2143.

${ }^{3}$ Pikulik, I.; Childs, R. F. Can. J. Chem. 1997, 55, 251-258. 


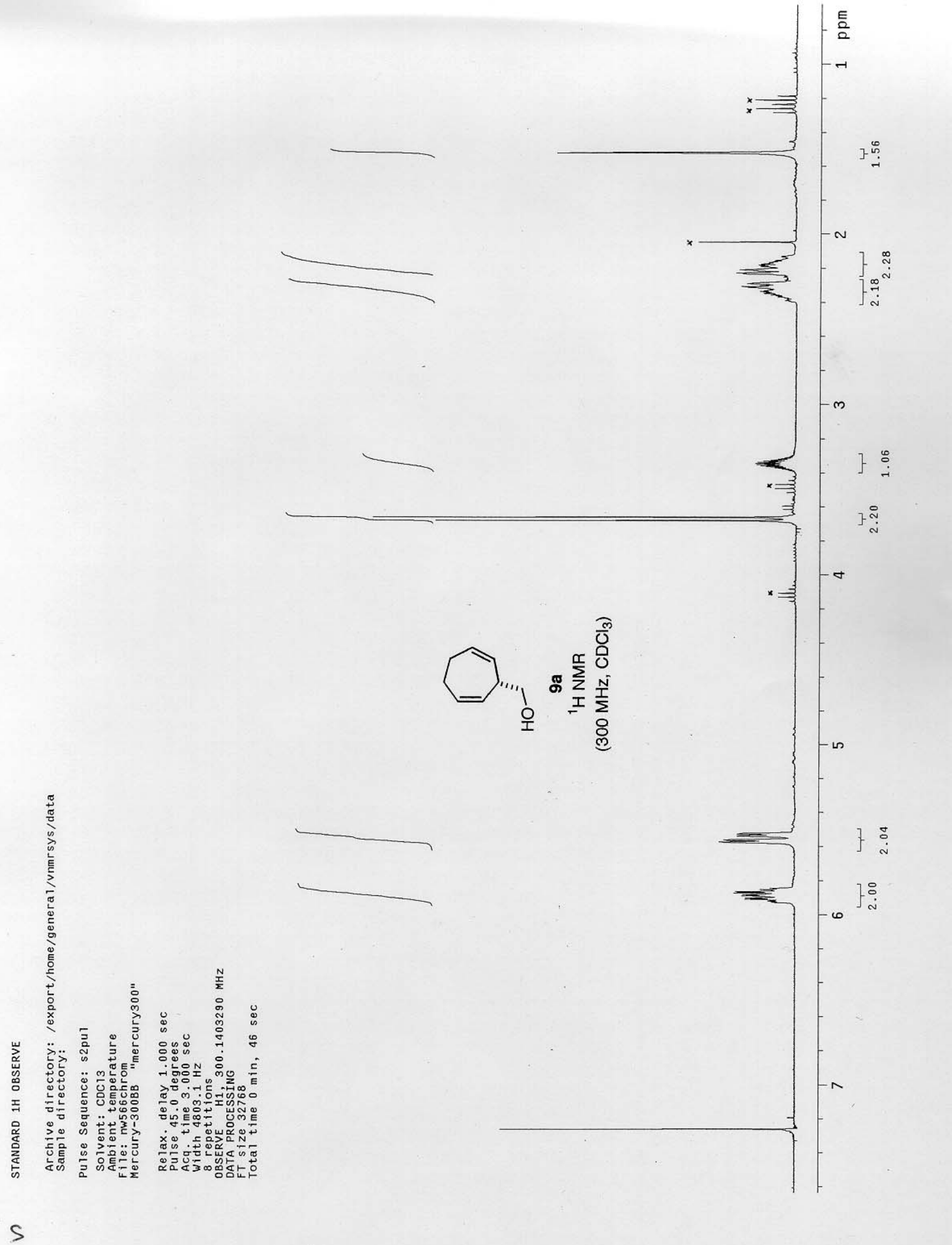




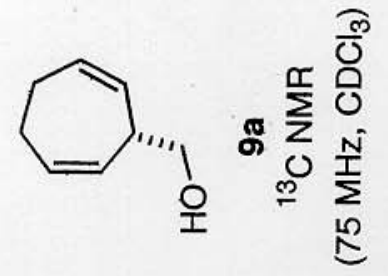

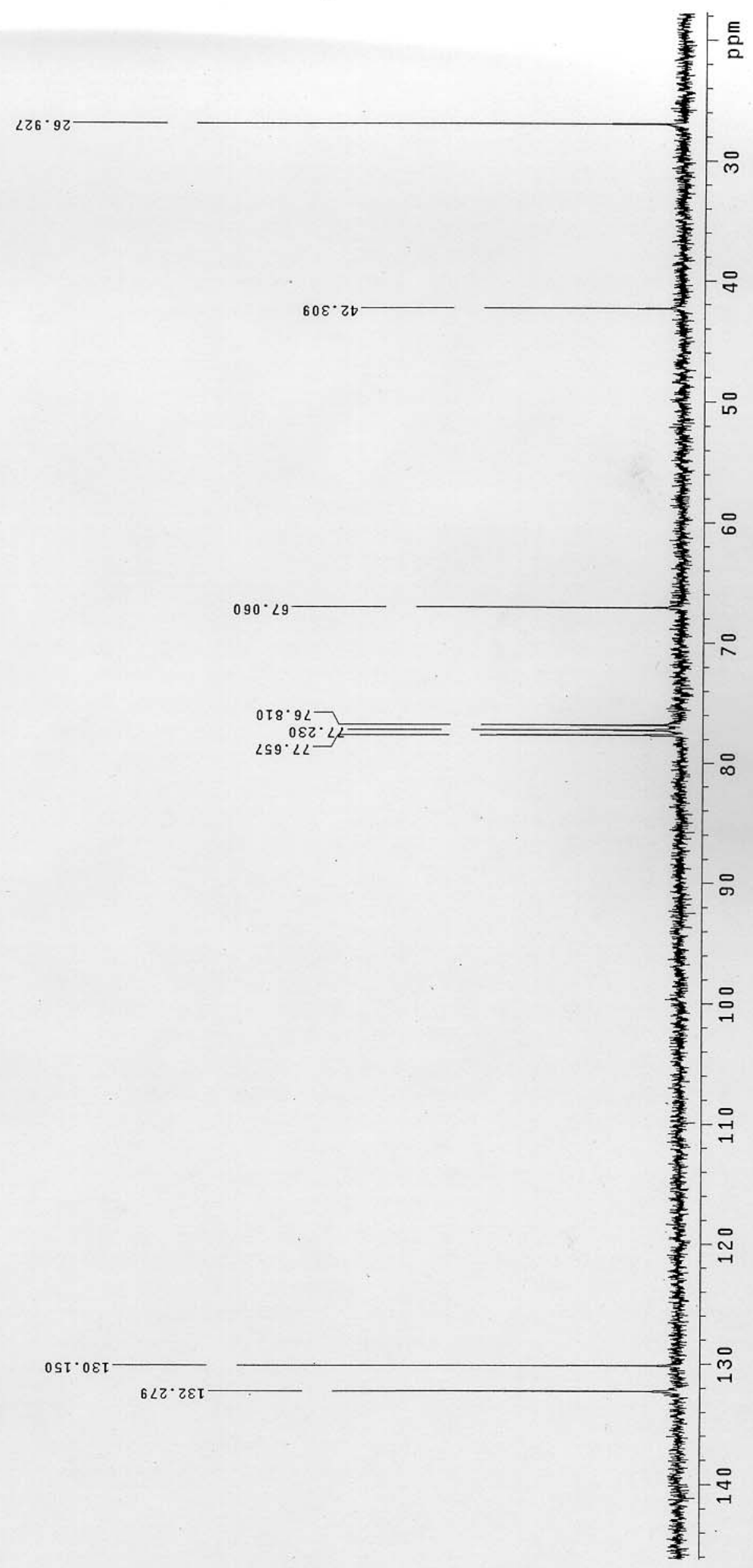




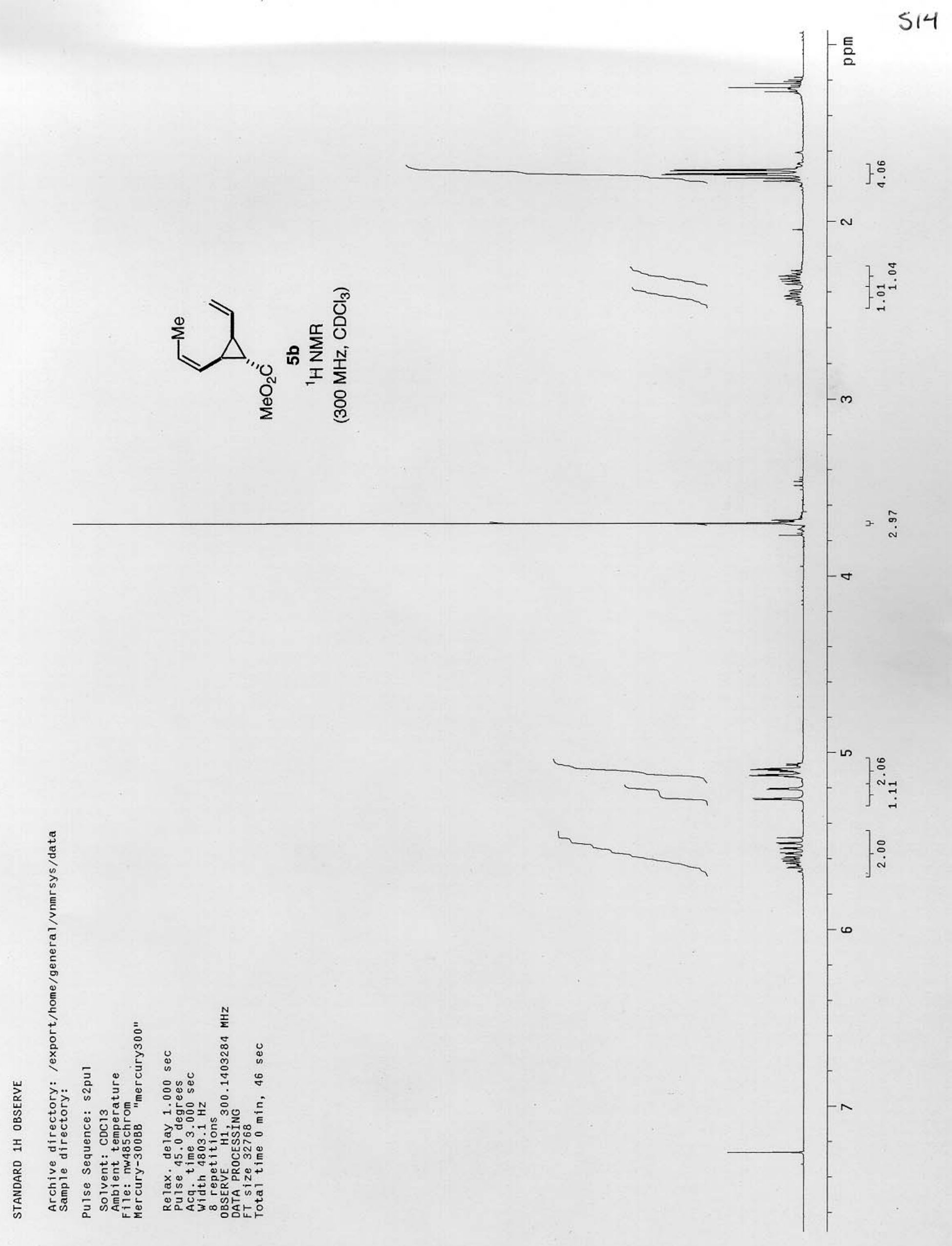



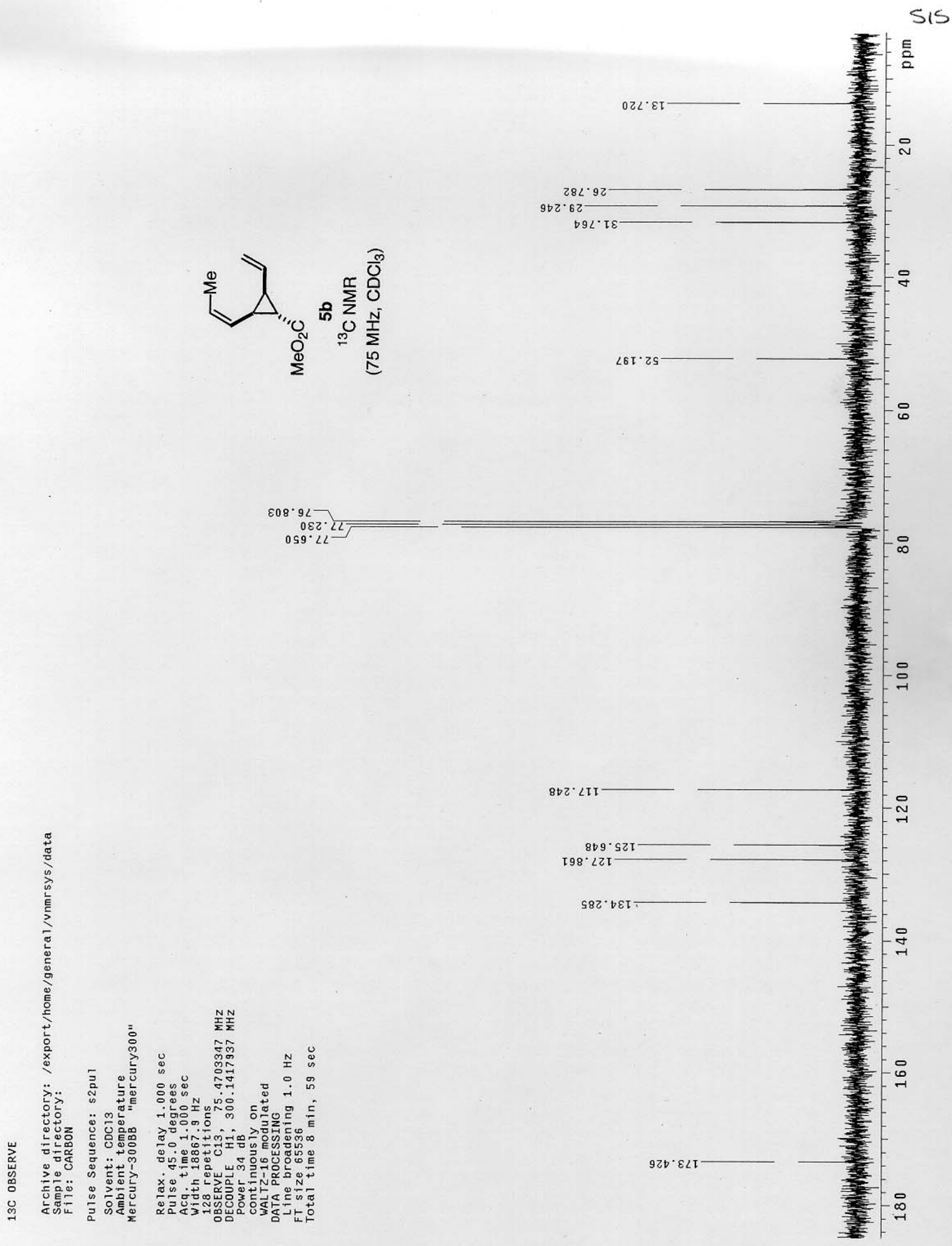



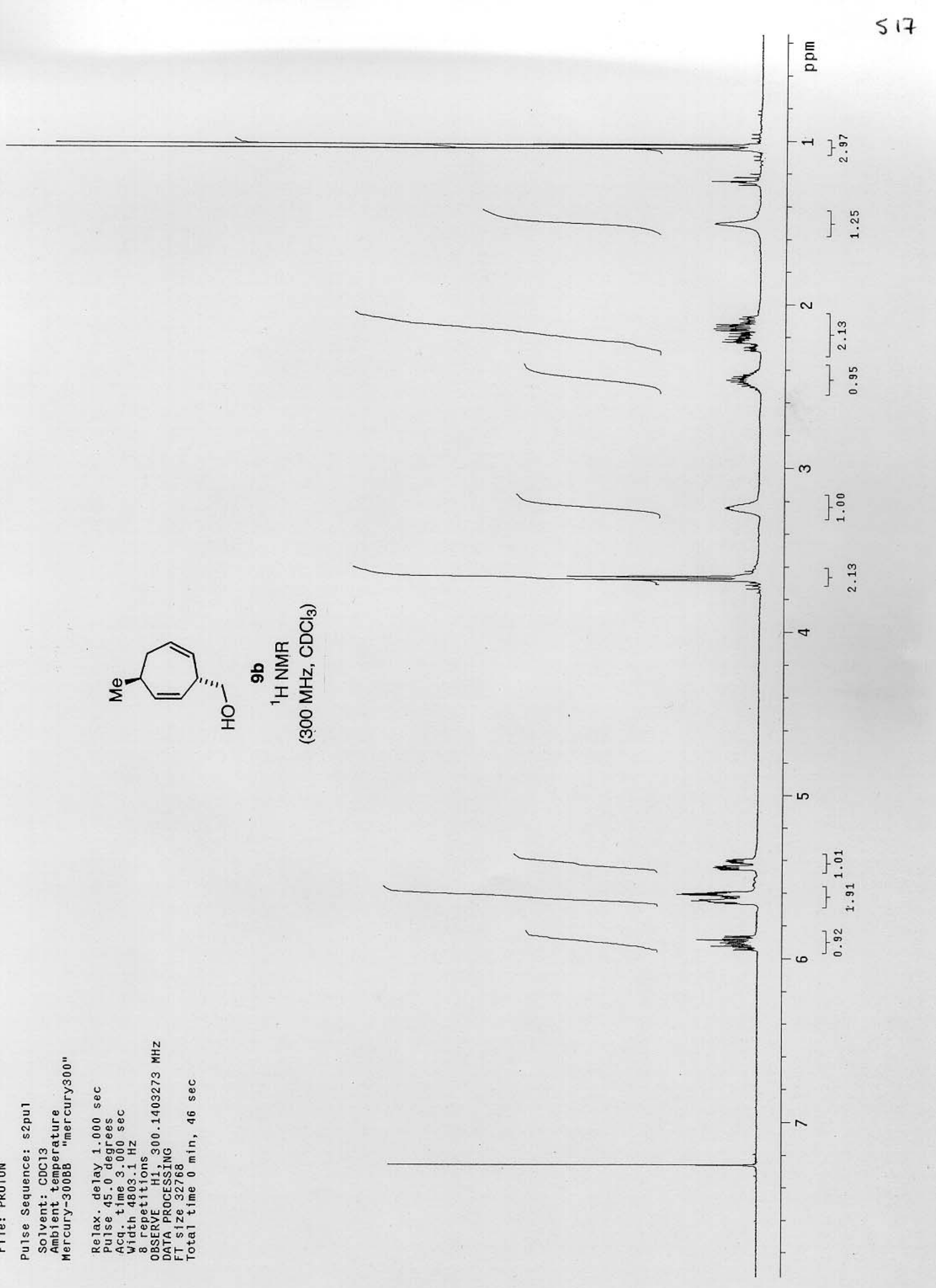




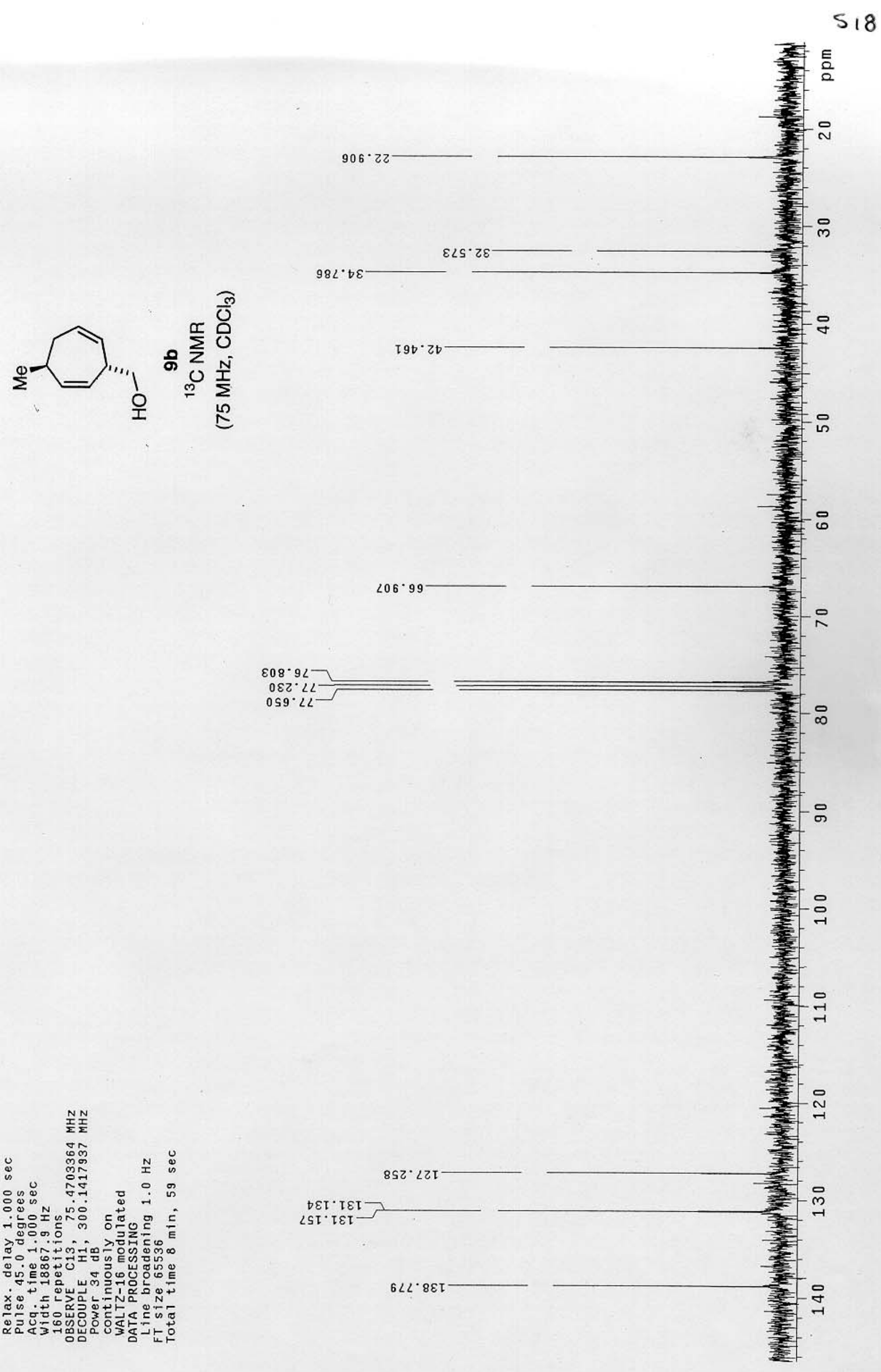




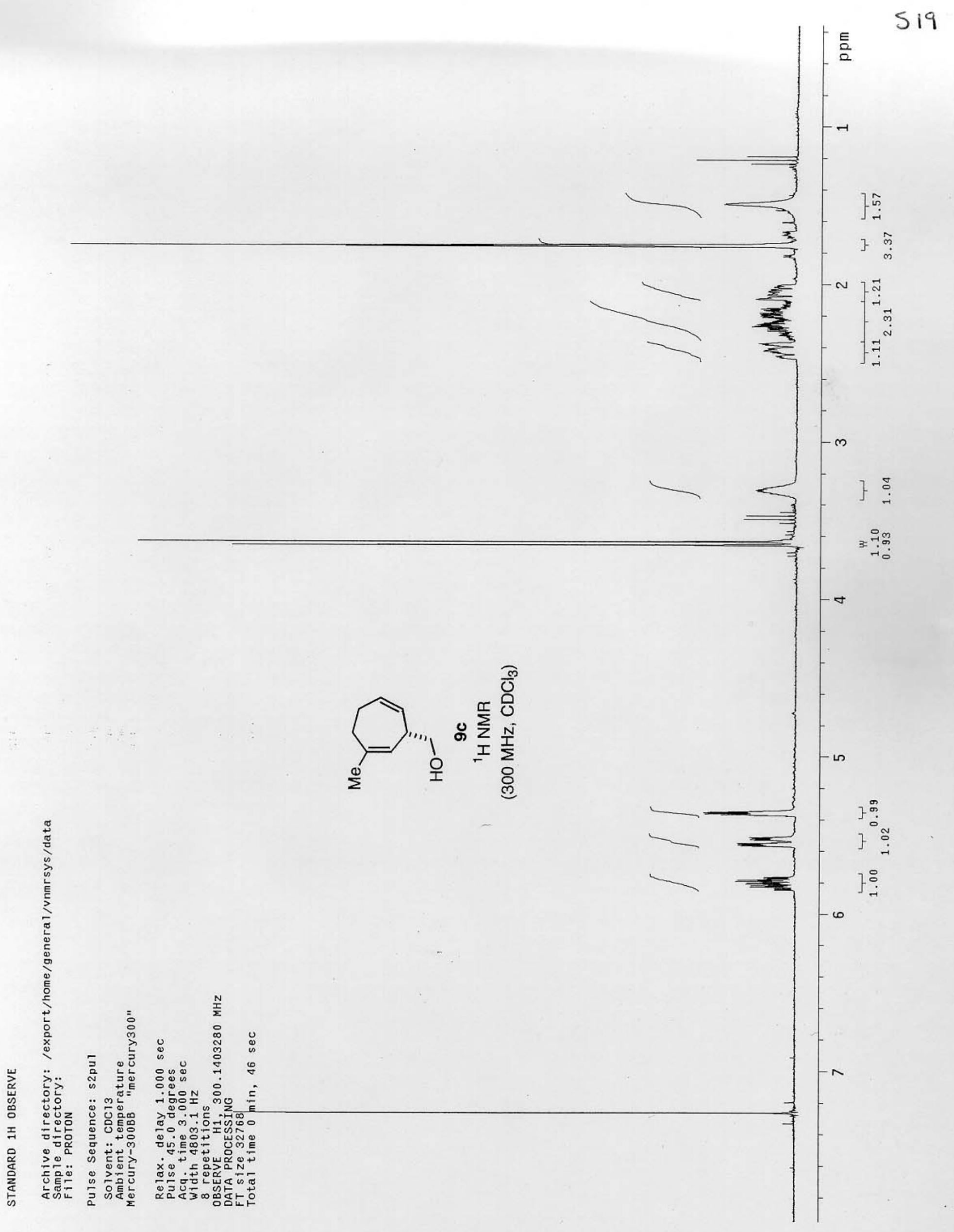


$\sum_{\sum}^{\infty} \cdots$ $969^{\circ} \tau \varepsilon$ $560.9 z-2+0.9 z$

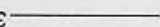
$S \angle L \cdot 0 t$
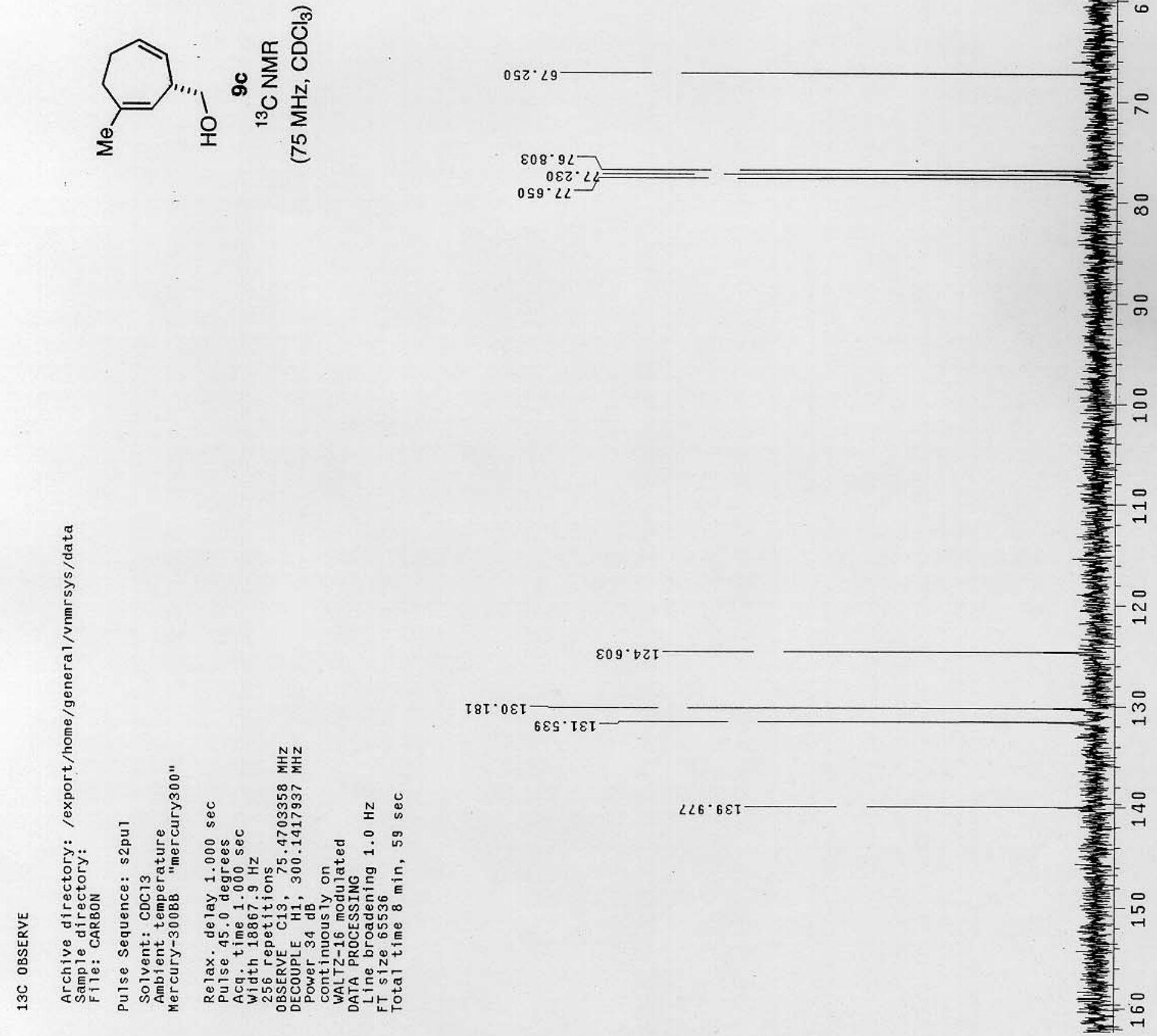

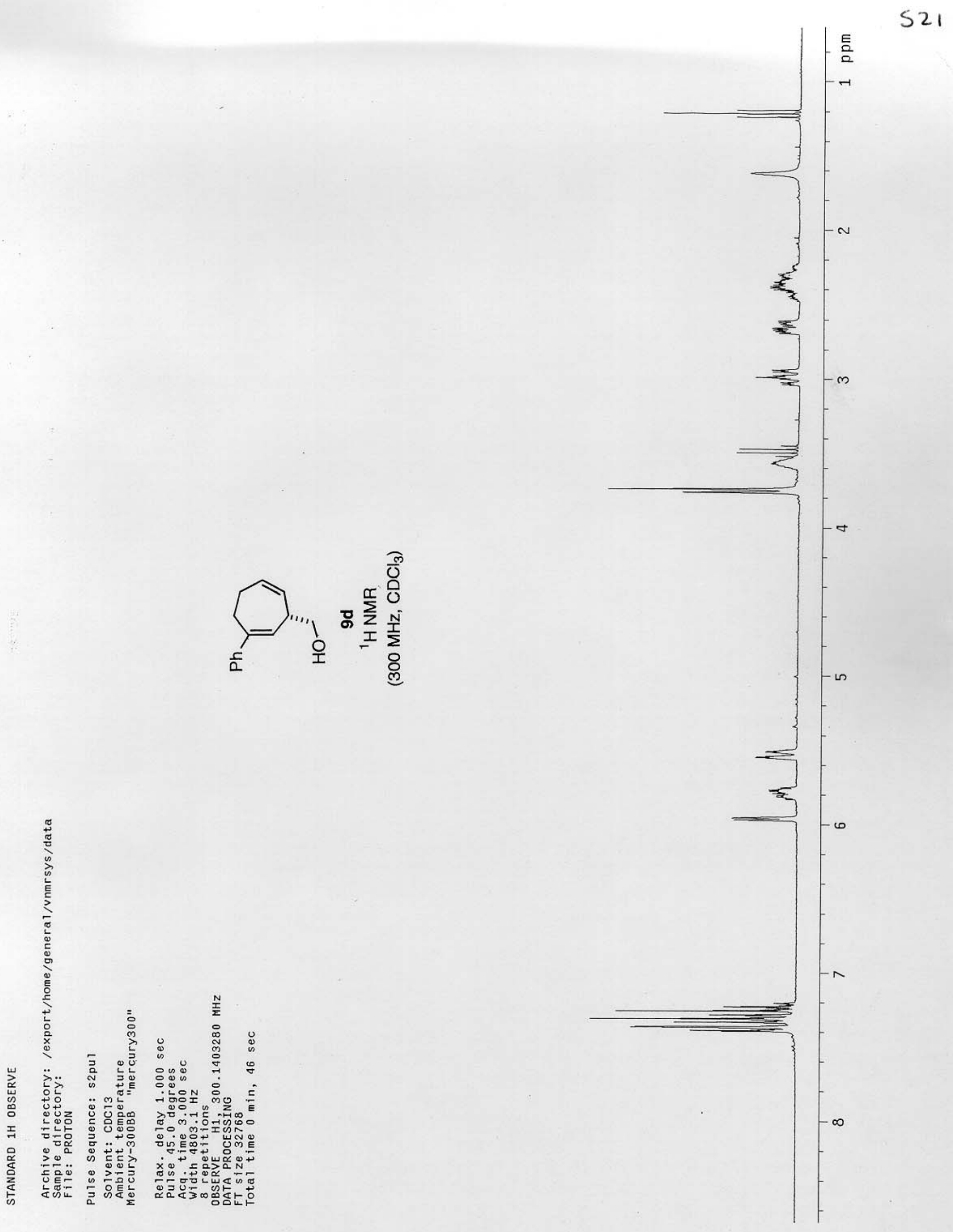
$\sum_{\frac{1}{2}}=\sum_{\frac{1}{\sum_{0}}}^{\frac{1}{0}} \sum_{\frac{1}{5}}^{\frac{0}{0}}$

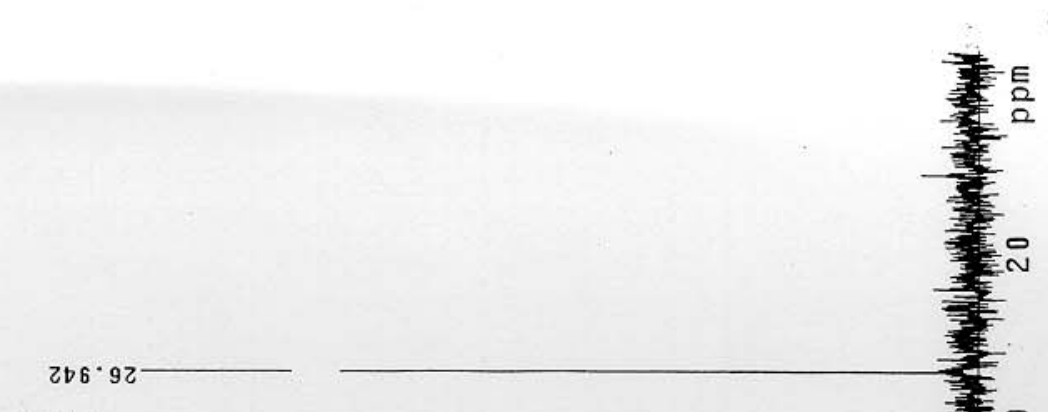

$0 \supset 0.0 \varepsilon$

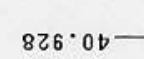

$68 I \cdot \angle 9$

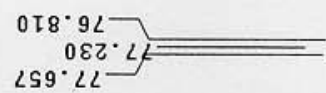

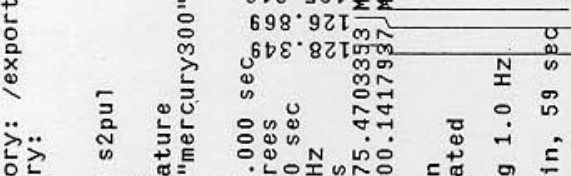

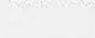




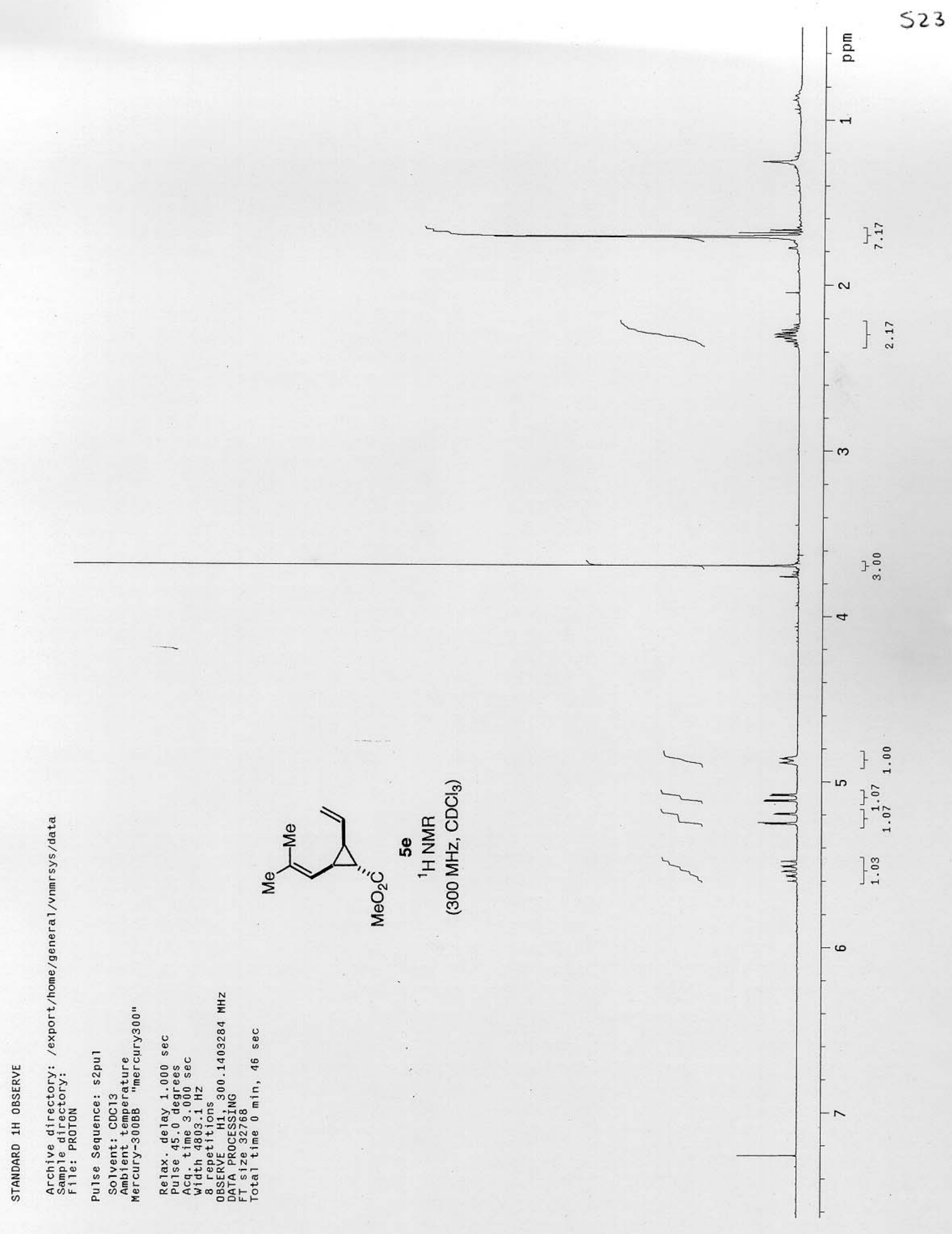




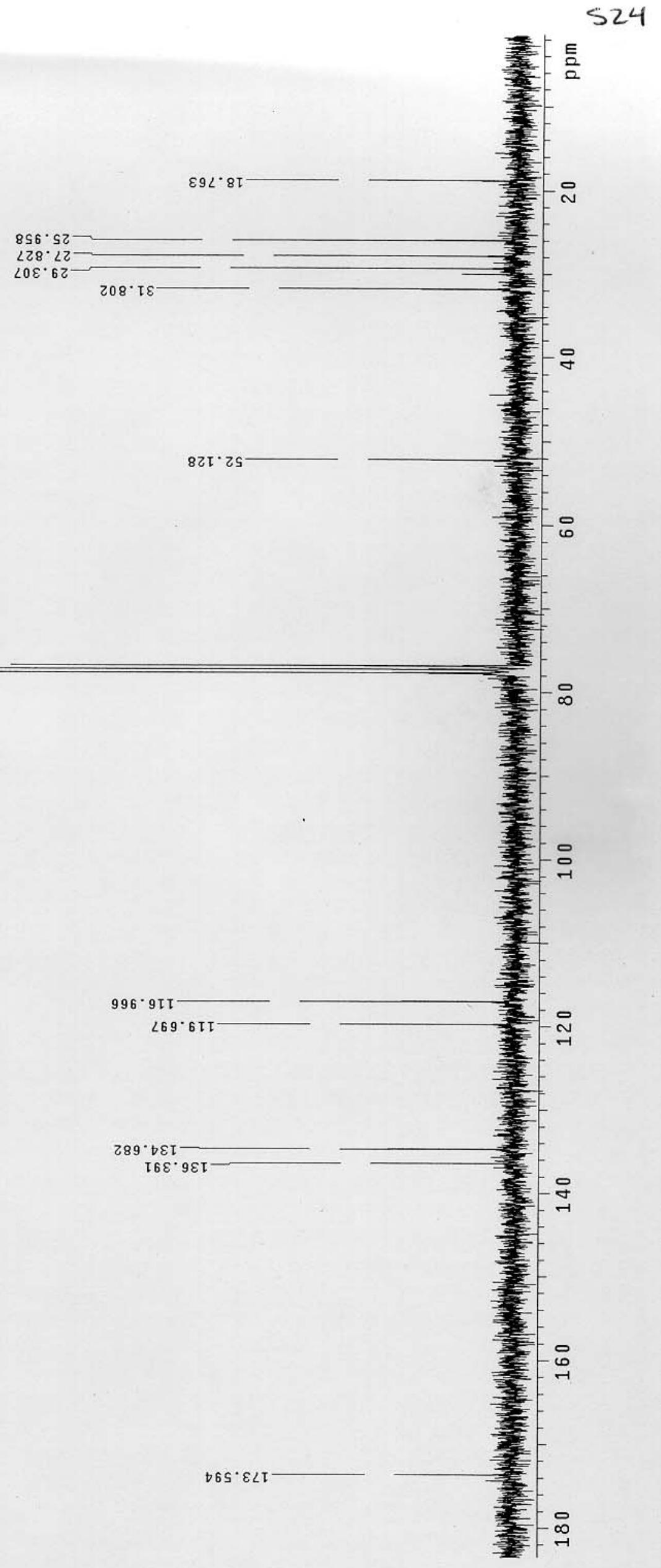




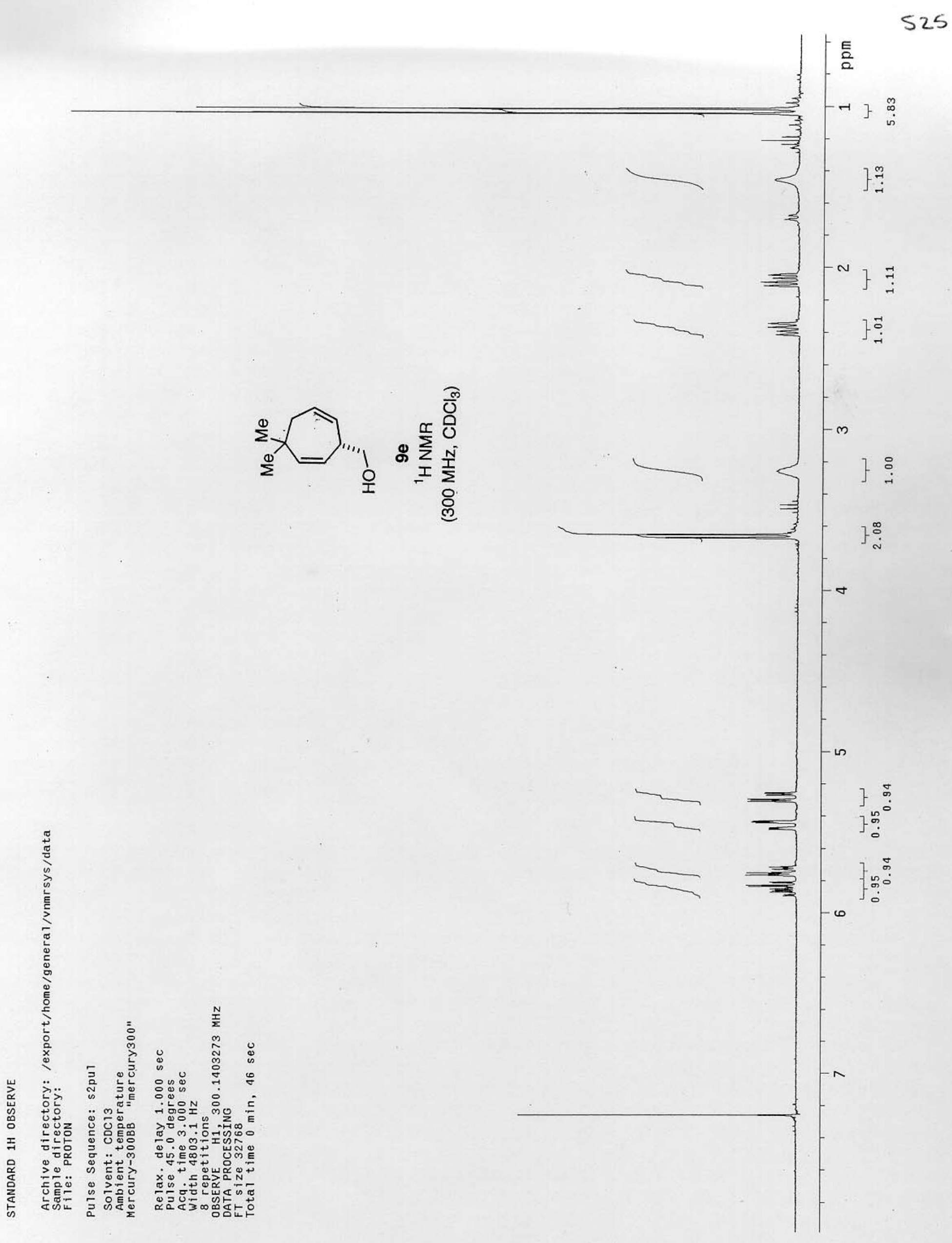



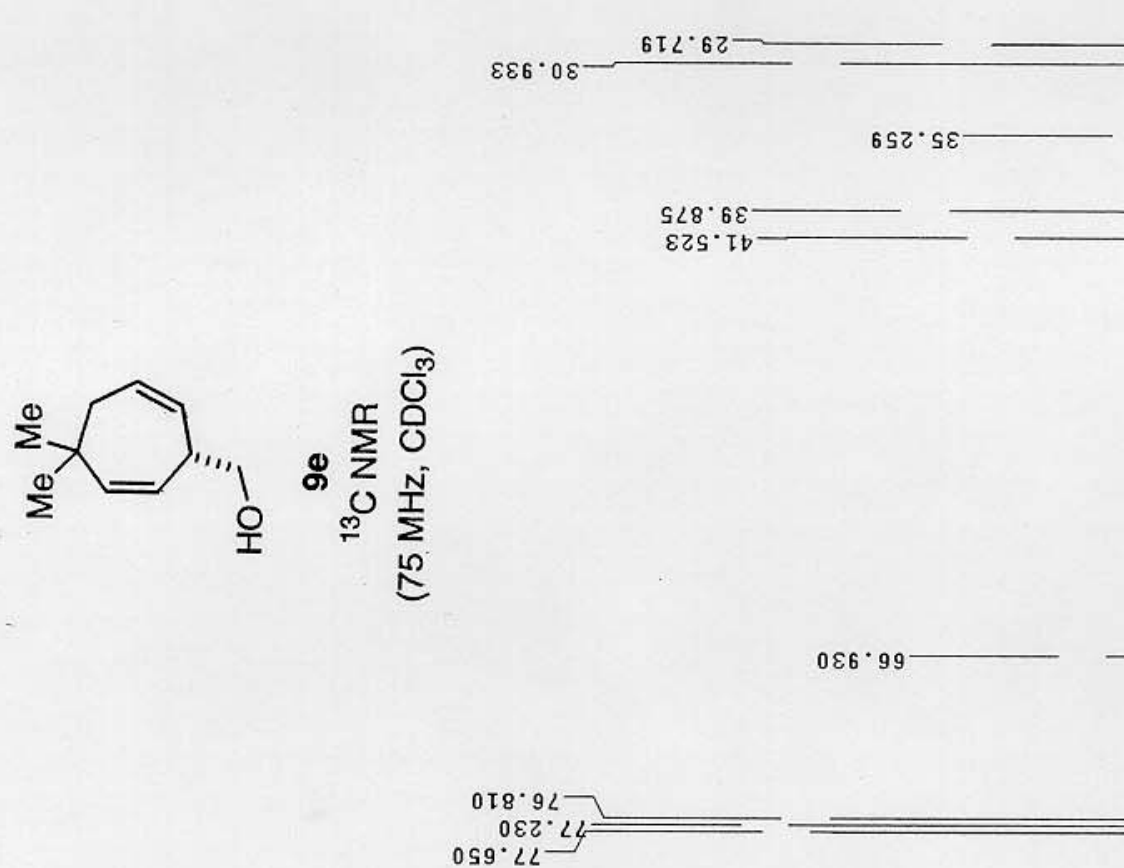

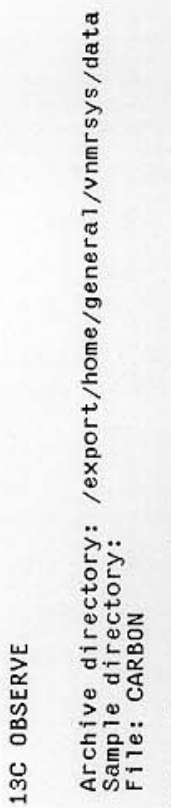
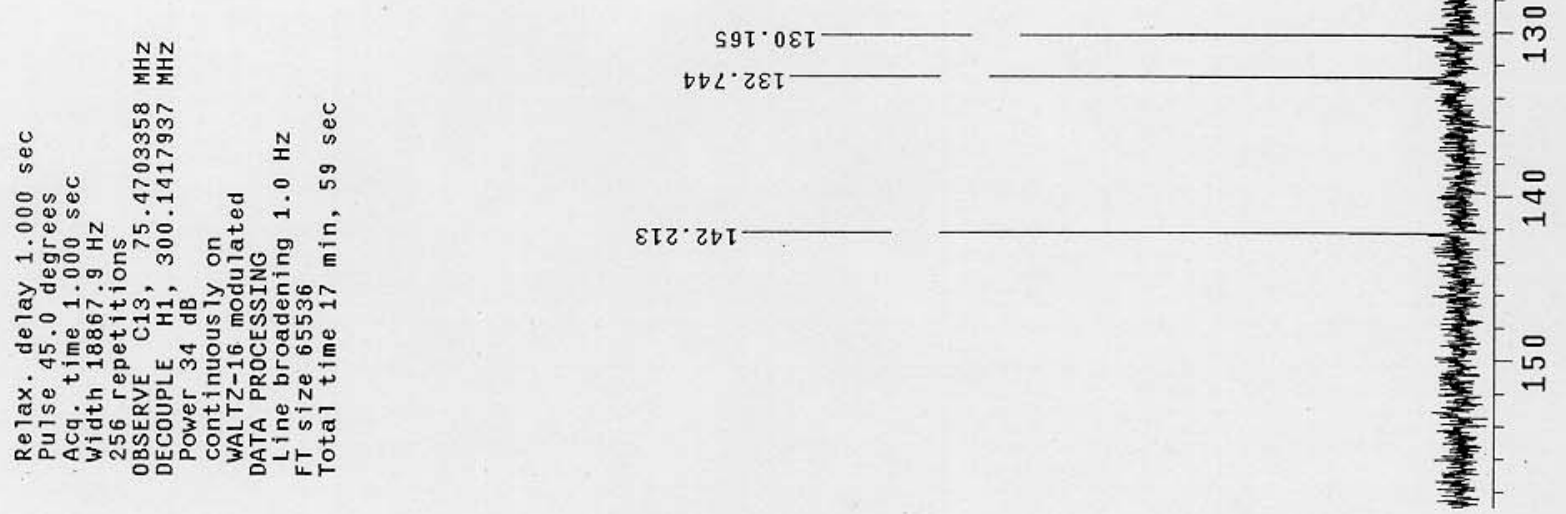


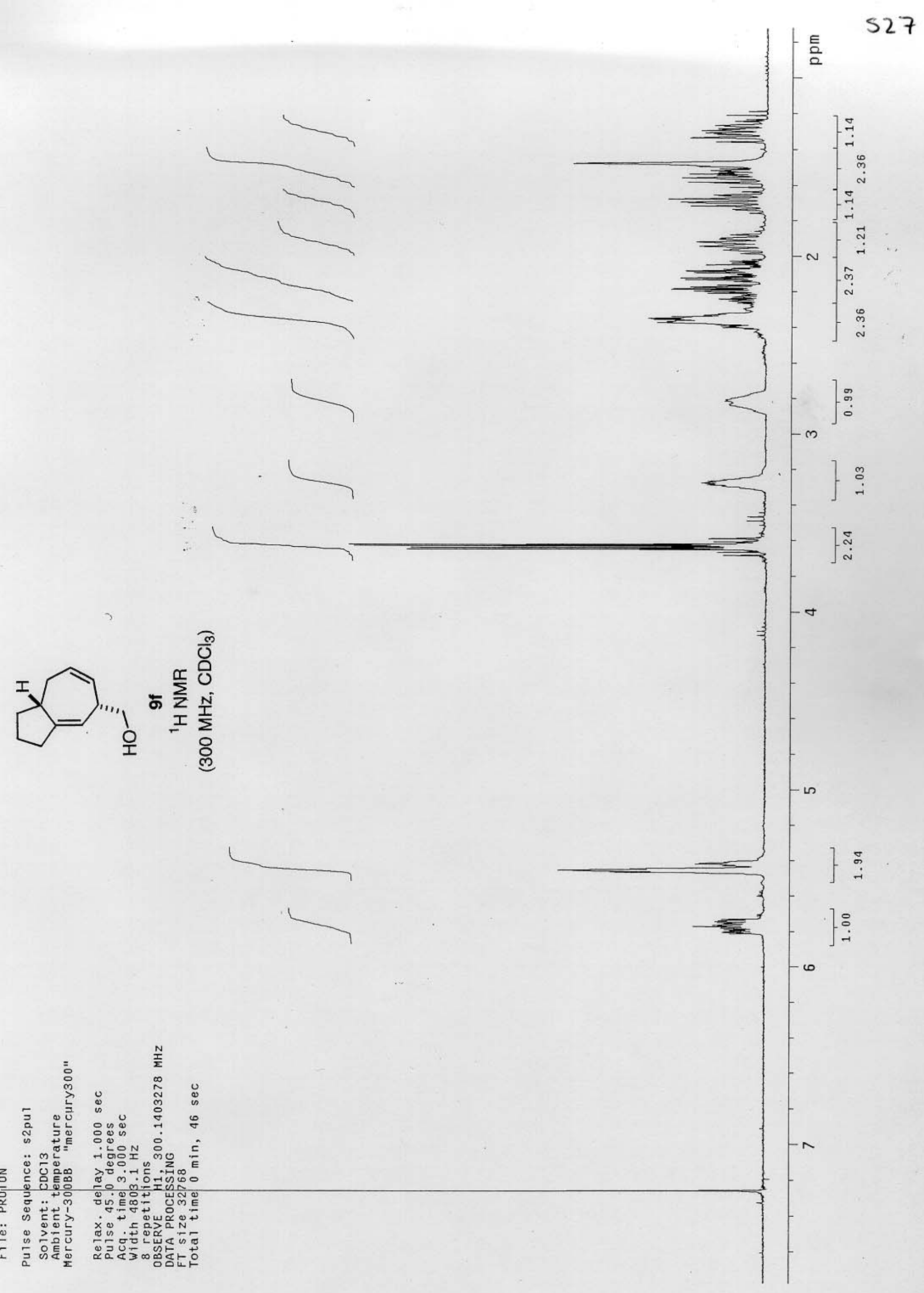




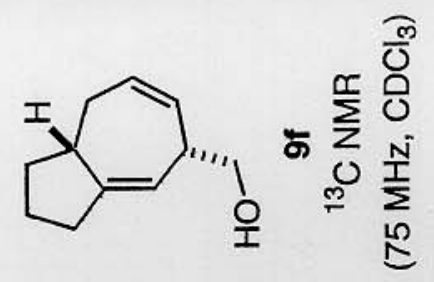

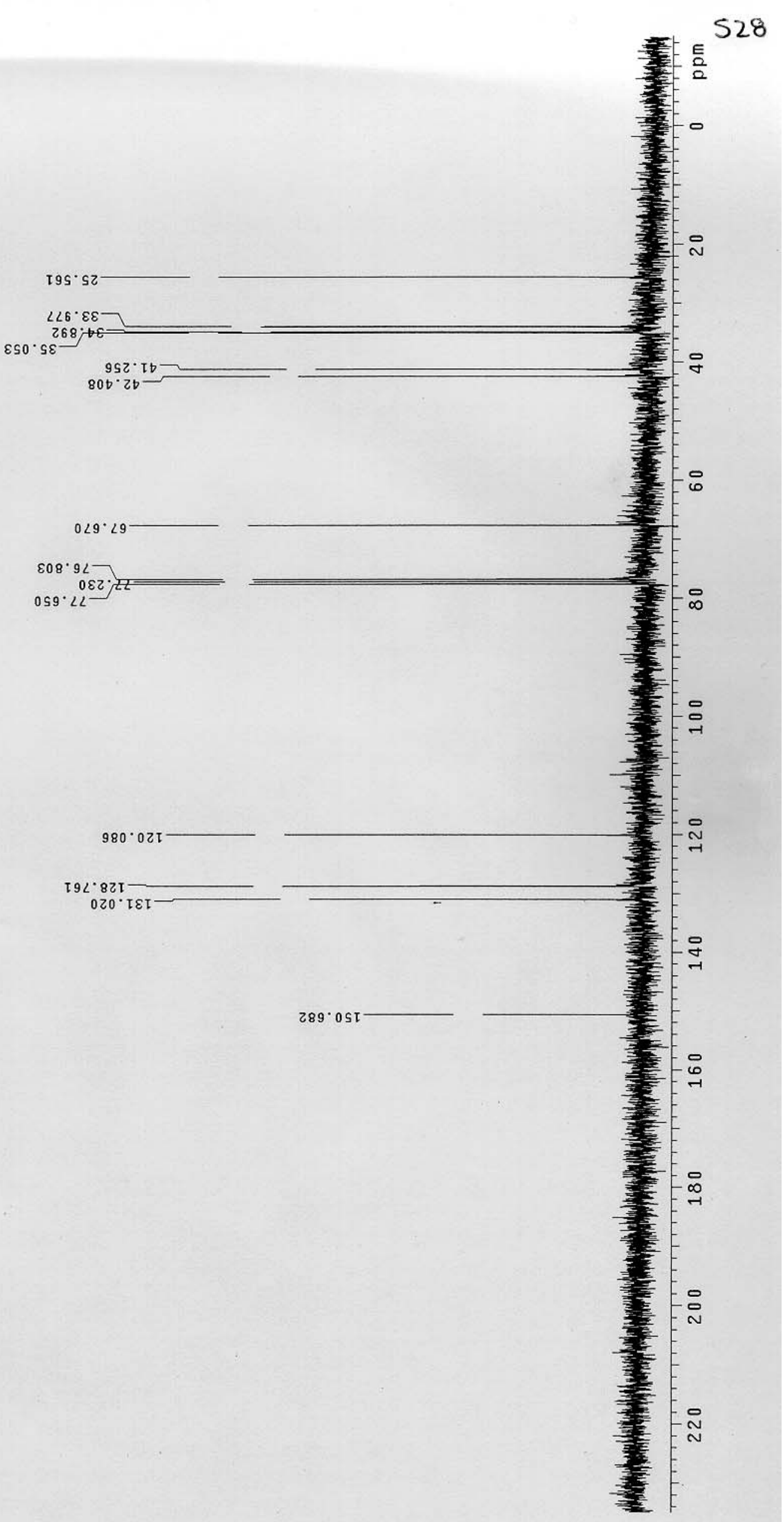

